\title{
歯肉剝離搔爬手術後の新付着に関する研究
}

一歯肉結合組織，歯根膜および歯槽骨由来の培養細胞 における形態的, 機能的検討一

\author{
林正 純 \\ 大阪歯科大学大学院歯学研究科歯周病学専攻 \\ (指導：山岡 昭教授） \\ (昭和 63 年 1 月 6 日受付)
}

\section{Morphological and Functional Study in vitro on Culture Cells Derived from Gingival Connective Tissue, Periodontal Ligament and Alveolar Bone}

\author{
Masazumi HAYASHI \\ Department of Periodontology, Osaka Dental University
}

(Director : Prof. Akira YAMAOKA)

It is suggested that the type of cells responsible for the initial repopulation to the root surface determines the repair process following flap surgery. Recent studies have indicated that cells derived from the periodontal ligament, in contrast to those from the gingival connective tissue and alveolar bone, have the potential to restore periodontal architecture with new attachment. However, several studies suggested that osteogenesis enhanced the new attachment. The purpose of the present study is to determine the phenotype of cells which leads to the periodontal regeneration with new attachment.

Culture cells were isolated the gingival connective tissue, periodontal ligament and alveolar bone by using explant method. After the three types of cells were compared in regard to morphology (light and transmission electron microscopy) and function (doubling time, saturation density, life span) in vitro, they were each co-cultured with dentin slices in $\mathrm{MEM}+10 \%$ FBS to study on their attachment phase. Dentin slices were picked up after 1, 3 and 7 days of incubation.

The phase-contrast microscopic findings showed that emigrating culture cells from gingiva and periodontal ligament appeared to be fibroblastic, while culture cells from alveolar bone had mosaic appearance. Little difference in ultrastructural features was found among the three types of cells, but cell junction and extracellular microfibrils were observed in cells from alveolar bone only. The log of growth curve showed that cells from periodontal ligament were inferior to those from gingiva and alveolar bone in the proliferation and migration potency. Concerning the attachment-activity to the root surface, cells from alveolar bone were superior to those from gingival and periodontal ligament.

These findings suggest that the osteoblast-like cells which appeared to the coronal root surface could, at least in part, be concerned in the new cementum formation in a limmited portion of supracrestal area.

本論文の要旨は, 第 30 回春季日本歯周病学会 (1987 年 4 月 17 日) および第 360 回大阪歯科学会例会（1987 年 6 月 30 日）におい て発表した。 
Key words : Culture, Fibroblast, Osteoblast, New cementum, New attachment

要旨：歯肉剝離搔爬手術後の新付着にどのような細胞 phenotype が関与するかを解明する目的で, ニホンザル歯 周組織（歯肉結合組織部, 歯根膜部, 歯槽骨再生部) 由来培養細胞について, 超微形態, 増殖速度, 倍加時間, およ び根象牙質面との付着様式を検索した。その結果, 形態学的には, 歯肉由来細胞および歯根膜由来細胞は, 線維芽細 胞様形態を示していたのに対し，歯槽骨由来細胞は，モザイク状を呈していた。超微構造的には，骨由来細胞のみ細 胞間接合や多量の未熟な微細線維の形成が見られた。増殖速度，倍加時間に関しては，骨由来細胞が他の細胞より優 れていた。根象牙質面との付着様式は, 各細胞間に際だった差異は観察されなかったものの, 骨由来細胞のみ, 根面 に対して積極的な付着傾向を示した。以上の所見から，歯槽骨頂部に限局してみられる新付着には，骨芽細胞様細胞 が関与することが示唆された。

索引用語 : 培養, 線維芽細胞, 骨芽細胞, 新生セメント質, 新付着

\section{緒言}

歯肉剝離搔爬手術後, より歯冠側での新付着獲得のた め，今日まで，硬軟両組織に対し種々の視点から多面的 アプローチがなされている。現在, 対硬組織に関しては, 新生歯肉により適切な根面を提供するため, 歯周疾患污 染根面に対する機械的 ${ }^{1 \sim 3)}$, 生物学的 ${ }^{4,5)}$, 化学的 ${ }^{6 \sim 10)}$ 等の 根面処置法が行われている。一方, 対軟組織の面では, 新付着を促進する細胞群を優先的に根面上に再集積させ ようとする試み ${ }^{11 \sim 13)}$ がなされている。すなわち, 軟組織 側からの術後の付着様式を考慮した場合，根面上に集積 する細胞群の特性がその付着形成に少なからず影響を与 える14 16) ことから, 現在研究の焦点は, 組織再構築に参 画する細胞 phenotype にあてられている。

細胞は，そのおかれている微小環境により，種々の構 造的, 機能的変化をうけるとともに, 常に活発な代謝を 行っている。線維芽細胞は，一般に細胞外基質コラーゲ ン線維の分泌, 合成に関与するとともに, その分解，吸

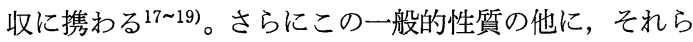
の存在する部位により，その特性を異にすることが明ら かにされている ${ }^{20)}$ 。近年, 歯周組織の再生に関連して, 歯肉結合組織由来打よび歯根膜由来細胞の機能的役割に ついて数多くの検索が行われている。これらの報告によ れば, 歯肉由来細胞が, 術後根面に集積すると, 根吸収 を惹起せしめ, 新付着成就には好ましくない21 23) とされ ている。一方，歯根膜由来細胞は，石灰化組織であるセ メント質, 骨の基質形成に関与すると考えられ ${ }^{24,25)}$, 新 付着にはこの細胞集積の必要性 ${ }^{11,14)}$ が唱えられている。 すなわち歯周外科処置後の再構築様式は, 構築細胞の domain が重要で ${ }^{14)}$, 新付着形成には, 概念的な考えでは あるが，歯根膜由来細胞がより早期に歯冠側へ移動する

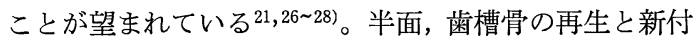

着との関連性についての検索もなされており29 37), 新付 着に対する骨再生部由来細胞の関連性も示唆されてい る $^{32 \sim 37)}$ 。

以上述べてきたように, 現在まで歯周組織各部細胞群 の根面一の対応について, 多面的分析はなされているも のの, なお末詳な点が少なくない。特に, 各組織由来細 胞群の増殖能, 付着様式を比較検討した研究は皆無であ る。そこで著者は，これらの歯周組織の治癒に関与する 細胞の構造や機能的役割を明確にするため，ニホンザル 歯周組織より歯肉結合組織由来 (Monkey Gingival Fibroblast $=$ MGF)，歯根膜由来（Monkey Periodontal Ligament Fibroblast=MPF), ならびに歯槽骨由来細胞 (Monkey Bone derived Fibroblast, Osteoblast-like cell=MBF) を単離, 培養し, それらの培養細胞につい て比較検討した。

\section{実験材料と方法}

\section{1. 培養細胞}

実験には，二ホンザル 1 頭を用い，健康歯肉結合組織 から単離した線維芽細胞 (MGF), および抜去歯歯根に 付着している歯根膜から単離した線維芽細胞 (MPF), そして歯槽骨骨再生部から単離した細胞 (MBF) を使用 した。

\section{2. 初代培養および継代培養}

まず各種細胞を得るために，あらかじめブラッシング およびスケーリングによるプラークコントロールを徹底 させたニホンザルを用いた。各種細胞のうち骨由来細胞 を得る前処置として, 上顎小臼歯部の歯肉を剝離した後, 煩側骨内にグルーブを入れ，さらに骨内グルーブへの歯 肉由来細胞の混入をさけるためミリポアフィルター (Millipore 社製) を介し, 歯肉弁を復位縫合した。術後 10 日目に Fig. 1 に示す様に, A の歯肉結合組織部, B の 


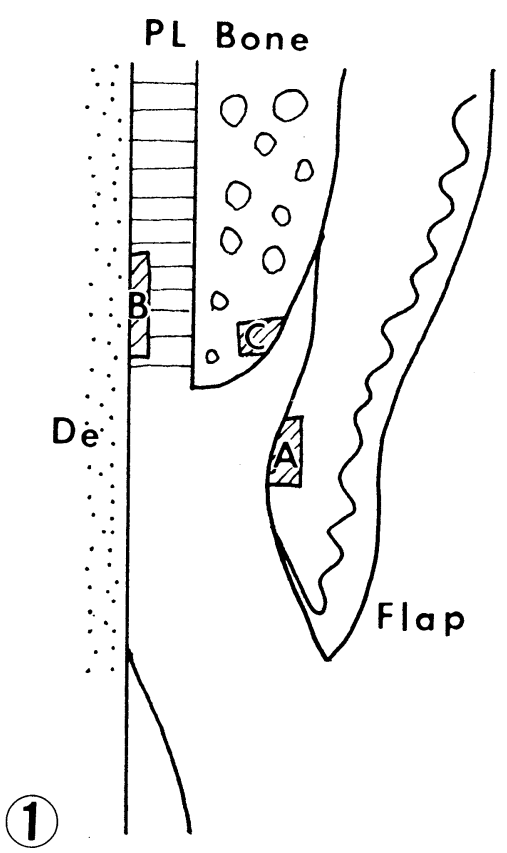

Fig. 1 Schema demonstrating the periodontal tissue after 10 days of flap surgery. Tissues are obtained from gingival connective tissue (A), periodontal ligament (B) and alveolar bone (C).

歯根膜部, および C の骨内グループ骨再生部より組織片 を採取した。そして，それら採取した組織片を，Phosphate Buffered Saline without $\mathrm{Ca}^{2+} \mathrm{Mg}^{2+}\left(\mathrm{PBS}^{(-)}\right)$ 中にて血液成分を十分に洗浄し, 続いて Messentimal Essential Medium (MEM) + Antibiotics (PenicillinStreptmycin solution, Pen. $500 \mathrm{u} / \mathrm{m} l$, St. $500 \mathrm{mcg} / \mathrm{ml}$ ) 中にて数回超音波洗浄し, 可及的に無菌状態とした。そ の後, 組織片を No. 15 Disposable Scalpels (FEATHER 社製) にて細切し, $35 \mathrm{~mm}$ プラスチック培養シャーレ (CORNING 社製) に貼り付け, 開放系にて初代培養を行 った。貼り付け後 3 日毎に培養液の交換を行い，4週目 に組織片より十分に遊出した細胞を，0.25\%トリプシン にて処理し, 採取した。得られた細胞を初代培養と同じ く, 増殖培地として, 抗生物質無添加の $10 \% \mathrm{FBS}$ 加 MEM を使用し， $5 \% \mathrm{CO}_{2}-95 \%$ air の条件下で $25 \mathrm{~cm}^{2} /$ Tissue Culture Flask (CORNING 社製) 中にて単層培 養した。実験に際しては, 培養初期, 継代 $3 \sim 5$ 代の培 養細胞を用いた。

\section{3. 培養細胞の同定}

a) 染色体分析

得られた継代 $3 \sim 5$ 代の各細胞を, カバーグラスを入
れた $35 \mathrm{~mm}$ プラスチック培養シャーレに $1 \times 10^{4} \mathrm{cells} /$ dish になるように植え込んだ。3 日間培養し,ついでコ ルセミド $\left(10^{-7} \mathrm{M}\right)$ を含む培養液に置換し，さらに 2 時 間培養した。培養液を捨て, $0.2 \% \mathrm{KCl}$ 液 $\left(37^{\circ} \mathrm{C}\right)$ を約 $1.5 \mathrm{~m} l / \mathrm{dish}$ 加え, 20 分間処理し, 細胞が十分に膨化し たのちに変法カルノア液約 $1.5 \mathrm{~m} l / \mathrm{dish}$ を加え, 10 分間 弱固定した。さらに固定液を換え, 30 分間強固定した。 その後 $2 \%$ ギムザ液で 20 分間染色し, 水洗, 乾燥の後, スライドグラス上に封入した。油浸レンズを用い光学顕 微鏡にて鏡検し, 写真撮影の後, 染色体分析を行った。

b) 形態学的分析

位相差䫓微鏡観察として, 各組織片からの細胞遊出状 況を, in situにて 1 週, 3 週および 4 週と経週的に観察 した。また継代を経て得た各々の細胞群 (PDL 3〜5) も 位相差顕微鏡を用いて観察した。

電子顕微鏡観察には, 初代培養の後得られた細胞で, 継代初期 (PDL 3〜5) のものを使用した。各々の培養細 胞 $\left(5 \times 10^{4} \mathrm{cells} / \mathrm{dish}\right)$ を, $35 \mathrm{~mm}$ プラスチック培養シ ヤーレ中で培養し, 3 日後 $0.1 \mathrm{M}$ カコジル酸ナトリウム (pH 7.2) 緩衝 $2.0 \%$ グルタールアルデヒドにて 1 時間 $4^{\circ} \mathrm{C}$ で前固定し, 洗浄の後, $0.1 \mathrm{M}$ カコジル酸ナトリ ウム $(\mathrm{pH} 7.2)$ 緩衝 $1.0 \%$ オスミウム酸で 30 分間後固定 を行った。次いで, エタノール系列による脱水を経て Epon 812 中に包埋, 重合した。超薄切片作成の後, 酢酸 ウラニールとクエン酸鉛の重染色を施し, HITACHI H800 透過型電子顕微鏡にて同定を兼ねて, 鏡検, 比較検 討した。

\section{4. 増殖曲線}

$35 \mathrm{~mm}$ プラスチック培養シャーレに $1 \times 10^{4} \mathrm{cells} / \mathrm{dish}$ になるように各細胞をまき, 24 洔間毎に血球䚺算板にて 細胞数を計測し, 細胞の増殖曲線 (growth curve), 倍 加時間 (doubling time) および飽和密度 (saturation density) を求めた。また, 得られた各培養細胞の生存曲 線（life span）を調べるため, 実験使用後も継代を続け, 継代間隔と継代数を記録した。

\section{5. 歯根面への付着様式}

各細胞群の歯根片（健全象牙質）への初期付着様式を 観察するため, 根象牙質片 $(5 \mathrm{~mm} \times 5 \mathrm{~mm} \times 2 \mathrm{~mm})$ を 35 $\mathrm{mm} \operatorname{dish}$ のプラスチック培養シャーレ中に置き, その上 に各細胞群 $\left(5 \times 10^{4} \mathrm{cells} / \mathrm{dish}\right)$ を各々植え込み, 培養し た。植え込み後 24 時間, 3 日そして 7 日目に, 歯根片を 取り出した。その後, $0.1 \mathrm{M}$ カコジル酸ナトリウム $(\mathrm{pH}$ 7.2) 緩衝 $2.0 \%$ グルタールアルデヒドにて 1 時間 $4^{\circ} \mathrm{C}$ で前固定し, 洗浄の後, $0.1 \mathrm{M}$ カコジル酸ナトリウム 

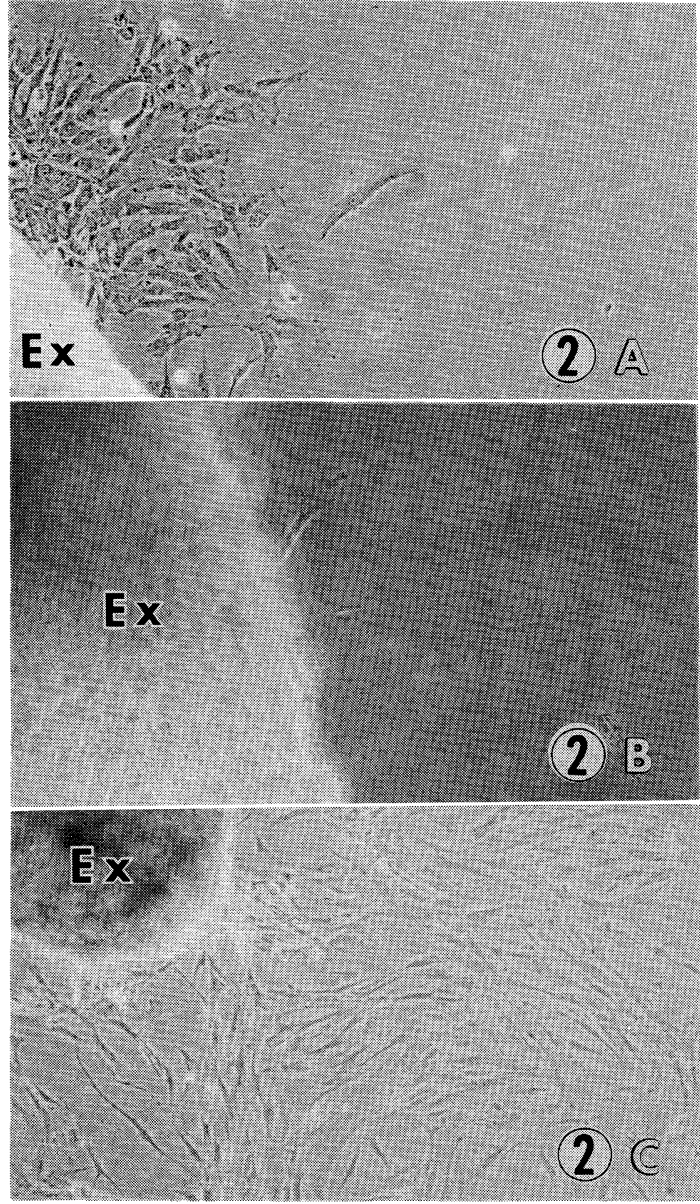

Fig. 2-A Phase-contrast micrograph of an explant (Ex) from gingival connective tissue (A) and cellular outgrowth after 7 days of culture. $(\times 100)$

Fig. 2-B Phase-contrast micrograph of an explant (Ex) from periodontal ligament (B) after 7 days of culture. $(\times 100)$ Few cellular outgrowth are observed at 7-day point of incubation.

Fig. 2-C Phase-contrast micrograph of an explant (Ex) from granulation of alveolar bone (C) and cellular outgrowth after 7 days of culture. $(\times 100)$

(pH 7.2) 緩衝 $1.0 \%$ オスミウム酸で 30 分間後固定を行 った。次いで, エタノール系列による脱水を経て Epon 812 中に包埋, 未脱灰にて超薄切片を作成した。酢酸ウ ラニールとクエン酸鉛の重染色を施した後, HITACHI $\mathrm{H}-800$ 透過型電子顕微鏡にて観察，比較検討した。
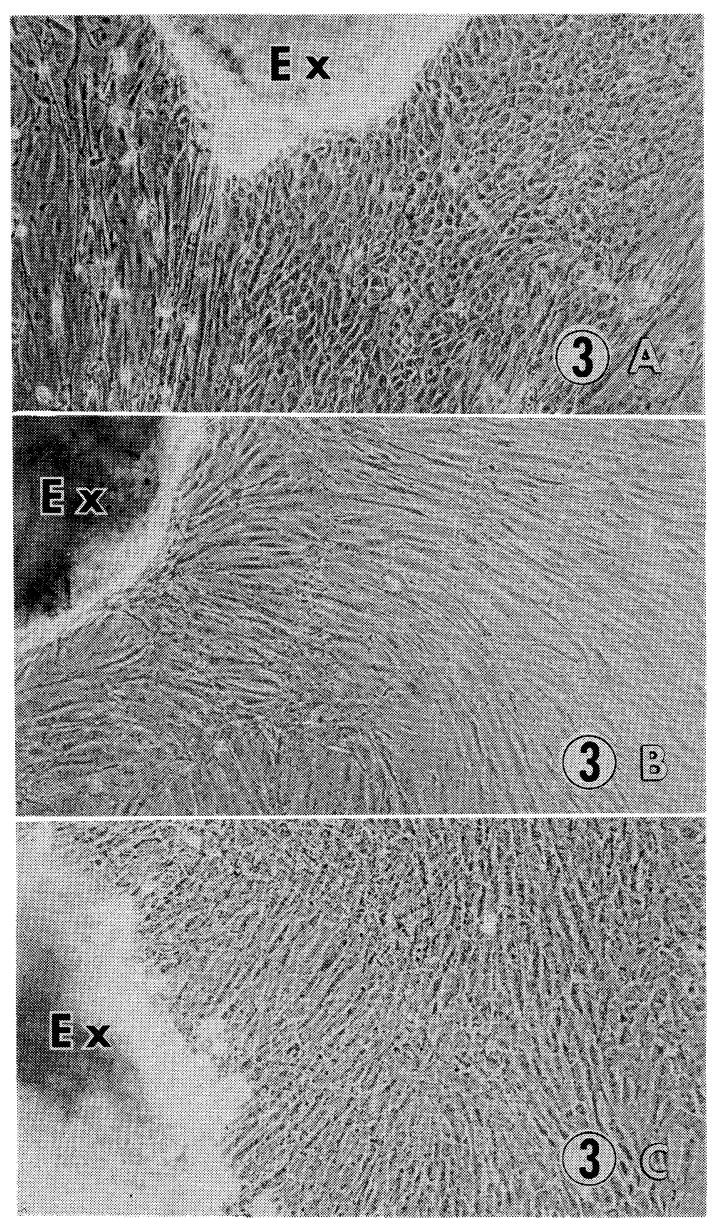

Fig. 3-A Phase-contrast micrograph of an explant (Ex) from gingival connective tissue (A) and cellular outgrowth after 3 weeks of culture. $(\times 70)$ Outgrowth of epithelial cells is observed.

Fig. 3-B Phase-contrast micrograph of an ex plant (Ex) from periodontal ligament (B) and cellular outgrowth after 3 weeks of culture. $(\times 70)$

Fig. 3-C Phase-contrast micrograph of an explant (Ex) from granulation of alveolar bone (C) and cellular outgrowth after 3 weeks of culture. $(\times 70)$

\section{実験成績}

\section{1. 初代培養}

歯肉由来および歯槽骨由来細胞は, 組織片貼り付け後, 1 週目に線維芽細胞様細胞の遊出が見られた（Fig. 2-A, 


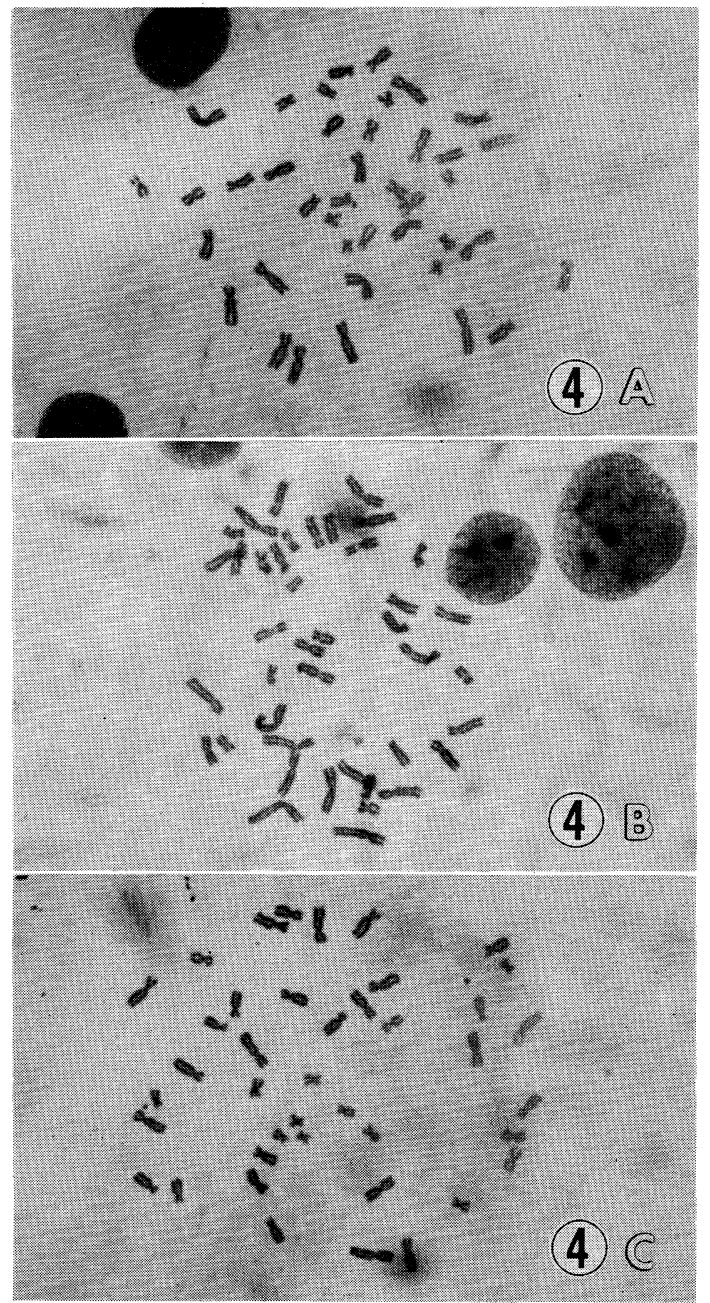

Fig. 4-A, B, C Photomicrograph displaying the chromosome of gingival cell (4-A), periodontal ligament cell (4-B) and alveolar bone cell (4-C). $(\times 1,000)$

No chromosome aberration is observed.

2-C)。歯根膜片からの細胞の遊出は 1 週目では，ほとん ど見られなかった (Fig. 2-B)。貼り付け後 3 週において は，単層細胞 (monolayer cell) の遊出がどの組織片か らも見られ，放射状に増殖していた（Fig. 3-A, 3-B，3C)。また歯肉片からは，上皮様細胞の遊出も活発に見ら れた (Fig. 3-A)。貼り付け後 4 週には, 細胞はシャーレ 面に飽和状態 (confluent) になり，採取することが可能 となった。

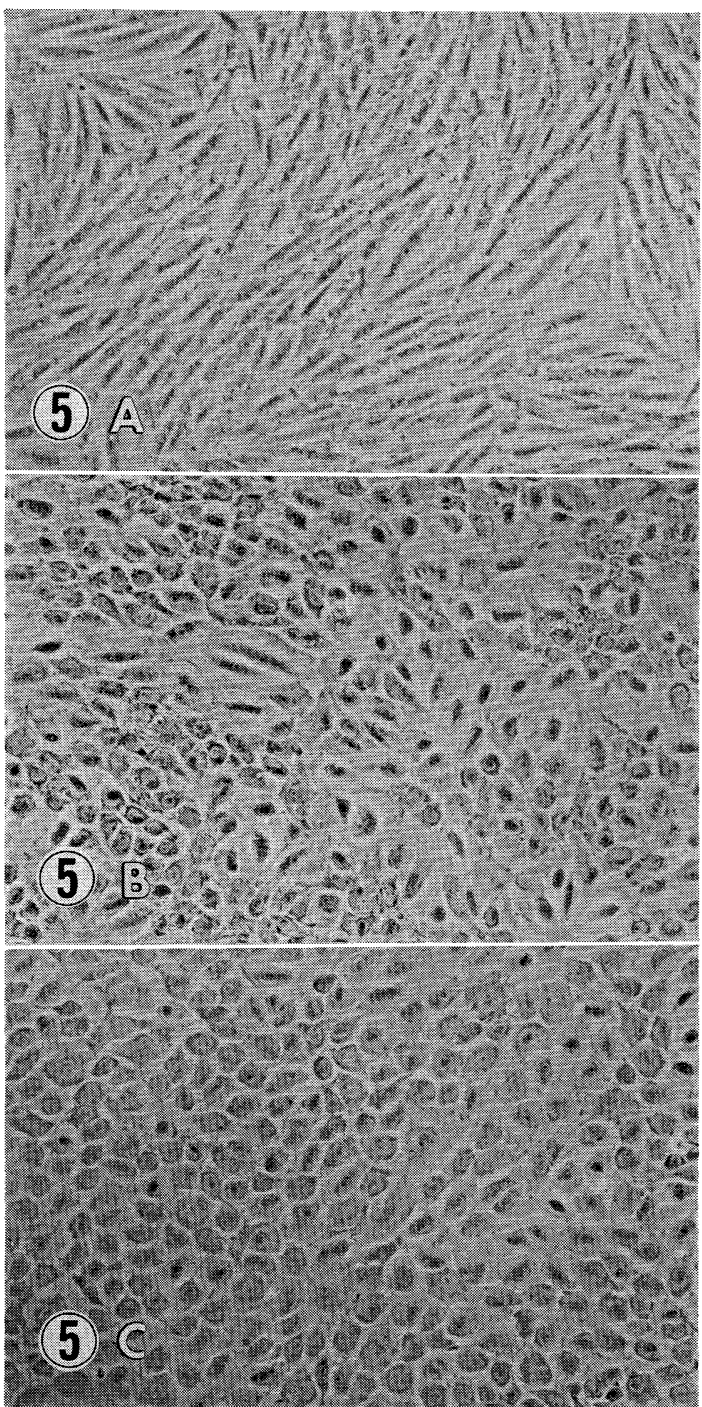

Fig. 5-A Phase-contrast microscopic appearance of culture cells (PDL 3-5) derived from gingival connective tissue. ( $X$ 100)

These monolayer cells have a fibroblastic appearance.

Fig. 5-B Phase-contrast microscopic appearance of culture cells (PDL 3-5) derived from periodontal ligament. $(\times 100)$ These monolayer cells have a fibroblastic morphology, but there was heterogeneity in these cells.

Fig. 5-C Phase-contrast microscopic appearance of culture cells (PDL 3-5) derived from alveolar bone. $(\times 100)$

These monolayer cells have a mosaic appearance. 
Table 1 General findings of electron micrograph of each culture cells.

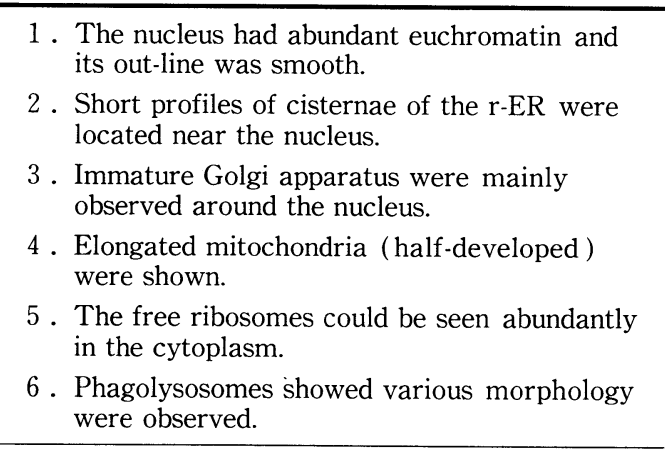

2. 細胞の同定

1) 染色体分析

各細胞は, 大型 metacentric の A 群を除く, 染色体 数 42 の二倍性細胞 (diploid cell) であった (Fig. 4-A, 4-B，4-C)。染色体チェックの結果, これらの単離され た培養細胞 (PDL 3～5) の正常性は，85\%以上を維持し ていた。

\section{2) 形態学的分析}

a. 倒立顕微鏡所見

歯肉由来, 歯根膜由来および歯槽骨由来の線維芽細胞 の位相差顕微鏡像は, すべて単層で飽和状態を示してい た。それぞれの形態に関しては, まず, 歯肉由来細胞 は, 典型的な紡錐形で, 線維芽細胞様形態を呈していた (Fig. 5-A)。歯根膜由来細胞は, 全体的には紡錐形を呈 するものの, 歯肉由来細胞に比べて丸みを帯びた細胞の 混在が認められ，不均一な様相を示していた (Fig. 5B)。しかし，歯槽骨由来細胞は，全体的に卵円形あるい はモザイク状を呈していた（Fig. 5-C)。

\section{b. 電子顕微鏡所見}

超微構造学的には， 3 種の培養細胞とも多くの面で所 見は共通しており, in vivo での基本的な形態を維持して いた。その一般的所見をまとめたものを, Table 1 に示 した。すなわち核は euchromatic であり, その外形は スムーズであった。核周囲には, 余り発達の良くない rough endoplasmic reticulum（以下 $r$-ER と略す）の half cisternae, Golgi apparatus, ならびに中等度に発達 した mitochondria が見られた。また全体に free ribosome に富み, 種々の形態を示す phagolysosome も観察 された。細胞によっては多量の空胞の存在も確認され た。

各細胞の超微構造的特徵については, 歯肉由来細胞の
核は heterochromatin に乏しく，その外形線はスムーズ であった。核膜の二重構造は明瞭であるが, 細胞内小器官 の発達は中等度であった。細胞と細胞の接触はいくらか の試料で見られたが, gap-type junctionあるいはattachment site は観察されなかった。核周囲に存在する Golgi fieldsには，多数の小胞が観察され，かつ大きな空胞 には, 電子密度の低い free granular material が認め られた (Fig. 6-A, 6-B)。

歯根膜由来細胞の超微形態も, 細胞内微細線維がやや 目立って見られたものの, 先の歯肉結合組織由来細胞と ほぼ同様の所見を呈した（Fig.7-A，7-B)。

さらに骨由来細胞も, 細胞内微細構造に関しては, 歯 肉由来細胞ならびに歯根膜由来細胞と概ね差異はなかっ た。しかし，この骨由来細胞では，細胞質に比べ核の占 める割合が多く, 卵円形の大きな核が観察された（Fig. 8-A, 9-A)。細胞内には, 多数の phagolysosome が目立 ち, 細胞間には, 細胞間結合の形成も見られた (Fig. 8B)。細胞の断端では, 電子密度の高いフィラメント束, および pinocytotic vesicle が観察された (Fig. 9-A)。 また, 細胞突起部では, 細胞外に多量の未熟な微細線維 が認められた (Fig. 9-B)。

\section{3. 增 殖 能}

各細胞の同定後，それぞれの増殖能力を比較するため に，増殖曲線を作成した（Fig. 10）。この増殖曲線によ ると, 培養 24 時間までは, 初期接種時のダメージがあり, 各細胞ともその細胞数は, 培養開始時の $1 \times 10^{5} \mathrm{cells} /$ dish を下回る約 $0.9 \times 10^{5}$ cells $/$ dish になっていた。培 養 24 時間以降では, 歯肉由来細胞および歯槽骨由 来細 胞は対数増殖に入り, 培養 48 時間 後には, 約 $2 \times 10^{5}$ cells/dish に増殖していた。しかしながら，歯根膜由来 細胞は, 培養 48 時間までは依然増殖が遅れ, その後対数 増殖に入った。すなわち, 歯根膜由来細胞のみその増殖 率の立ち上がりが悪く, 対数増殖期に入るのに他の細胞 より 24 時間の time lag を認めた。

この増殖曲線をもとに，倍加時間を求めた。結果は Table 2 に示す通りで, その速さは, 骨由来, ついで歯 肉由来, 歯根膜由来の順で, 各々 45.2 時間, 50.1 時間, そして 63.0 時間であった。

飽和密度に関しては， 3 種の培養細胞とも全体的に低 いものの, とくに差異はなく, 約 $3.1 \times 10^{5} \mathrm{cells} / \mathrm{dish}$ で あった（Table 2)。各細胞の大きさに関しては，この飽 和密度の結果から計算するとほぼ同一であった。

生存曲線に関しては, Fig. 11 に示すように, 各細胞と も概ね差異は認められず, 継代 10 代前後において対数増 

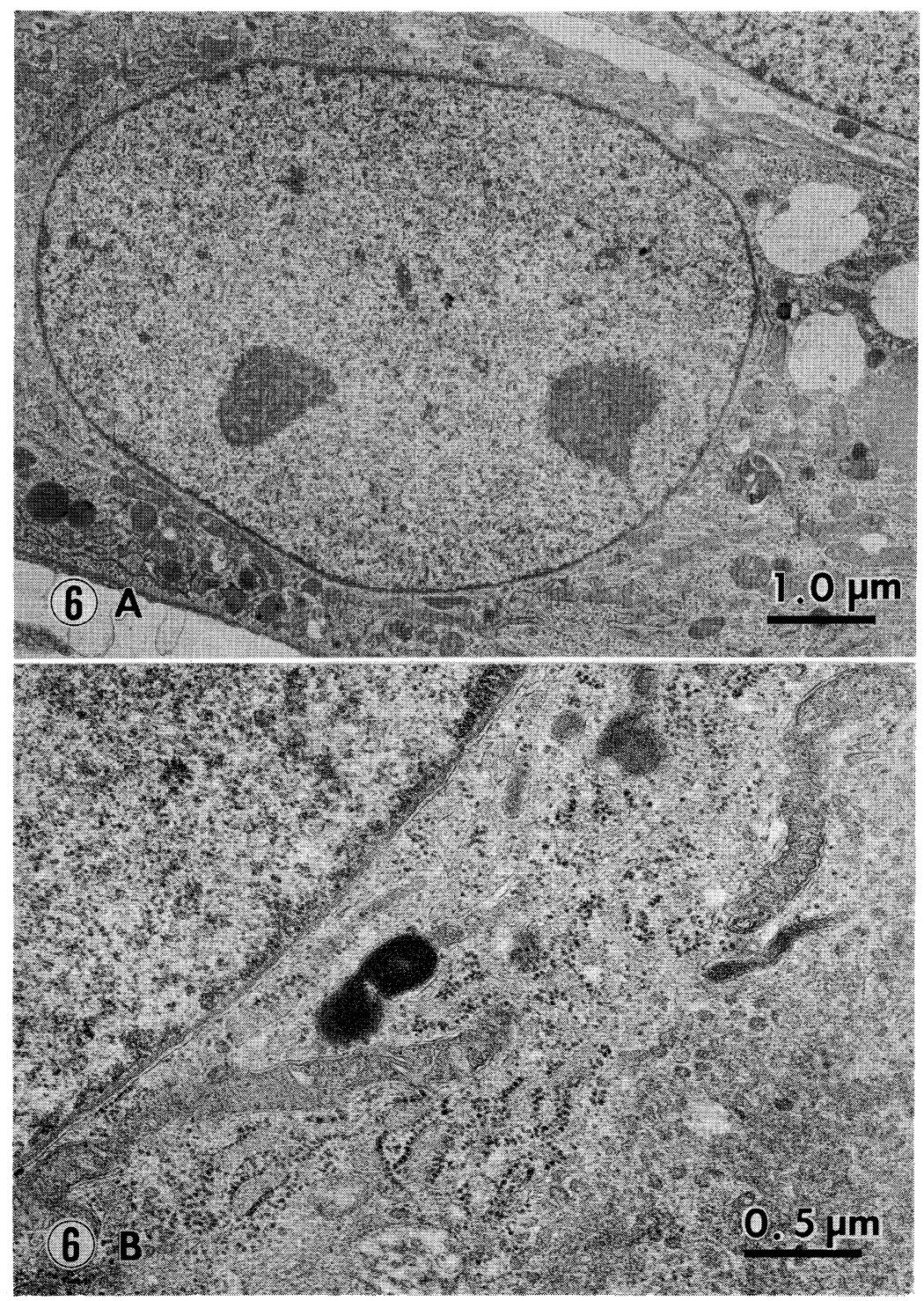

Fig. 6-A Electron micrograph of Fig. 5-A (cells derived from gingival connective tissue).

Euchromatic nucleus have a smooth out-line.

Fig. 6-B High-power magnification of Fig. 6-A.

Paranuclear cytoplasmic portion have r-ER half-cisternae, several Golgi fields with narrow cisternae and small vacuole.

殖期に入り, 継代 40 代前後で定常期, そして継代 50 代前 後で死滅期へと移行した。また各細胞の形質転換もみら れなかった。しかしながら, phase Iにおける継代間隔は, 前後の増殖曲線に相関して, 歯肉由来および歯槽骨由来 細胞は各々 5 日に一度であるのに対し, 歯根膜由来細胞
は 7 日に一度の割合であった。死滅期への移行も, 歯根膜 由来細胞のみ他の 2 者より $3 \sim 5$ 代早い所見が得られた。

4. 根象牙質面と各種培養細胞との付着様式 培養 1 日

歯肉由来細胞は，象牙質面によく伸展していた。しか 

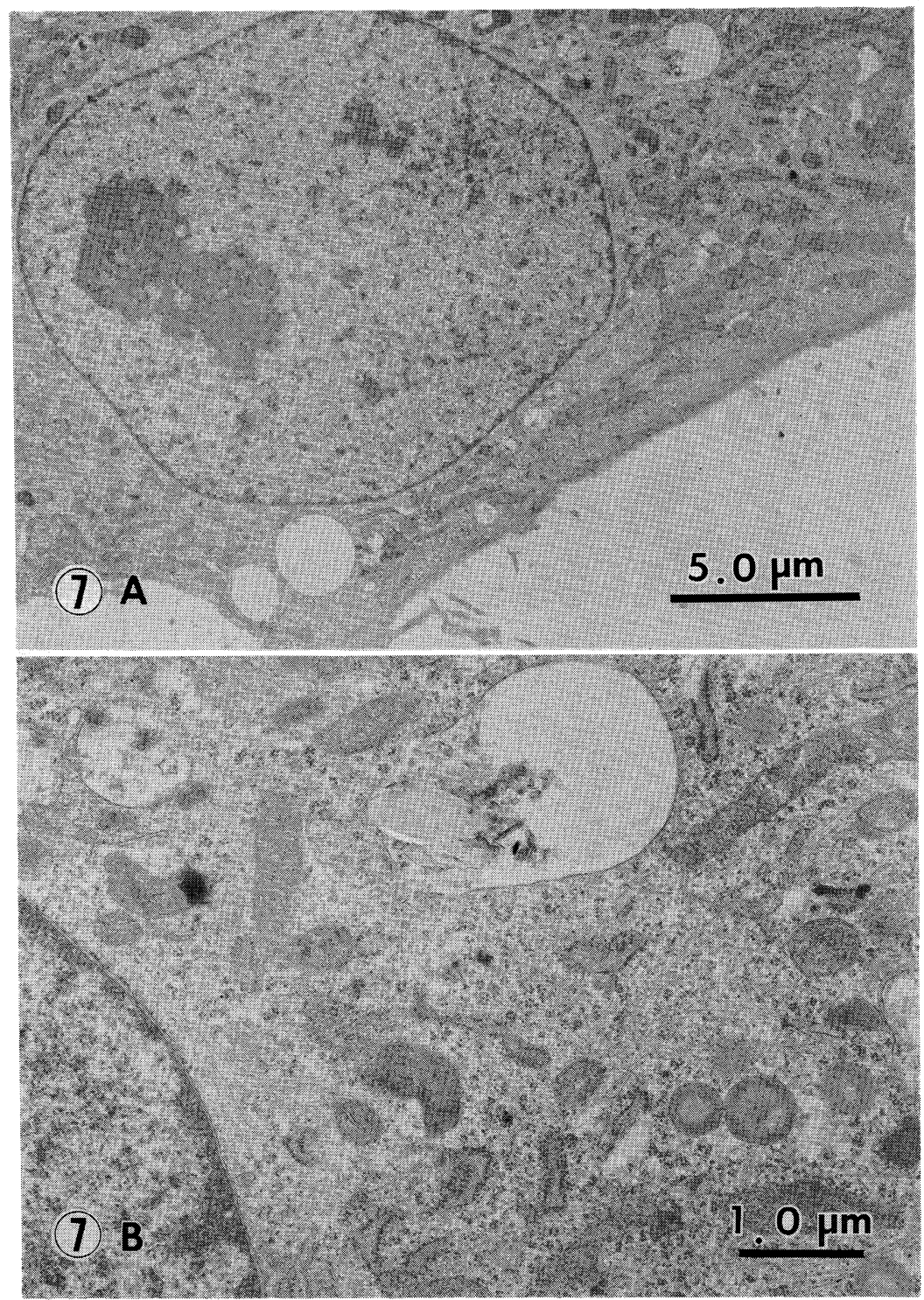

Fig. 7-A Electron micrograph of Fig. 5-B (cells derived from periodontal ligament).

These culture cells resemble the TEM's feature illustrated in Fig. 6-A, B.

Fig. 7-B High-power magnification of Fig. 7-A.

Cytoplasmic filaments are depicted at cytoplasmic periphery.

しながら，細胞のごく一部が象牙質突出部と接触してい る以外, 大部分は根面と距離を隔てていた (Fig. 12-A)。

歯根膜由来細胞においても，歯肉由来細胞と同様の付 着状況を示していたが, 細胞突起の伸展は, 歯肉由来細 胞に比べ劣っていた (Fig. 12-B)。
歯槽骨由来細胞も，先の細胞と概ね同様な付着状況で あった。しかし, 前 2 者に比べ, phagolysosome, lipid droplet が目立ち, r-ER の発達も良好で; 細胞の一部に pinocytotic vesicle の並列が認められた (Fig. 12-C)。 培養 3 日 

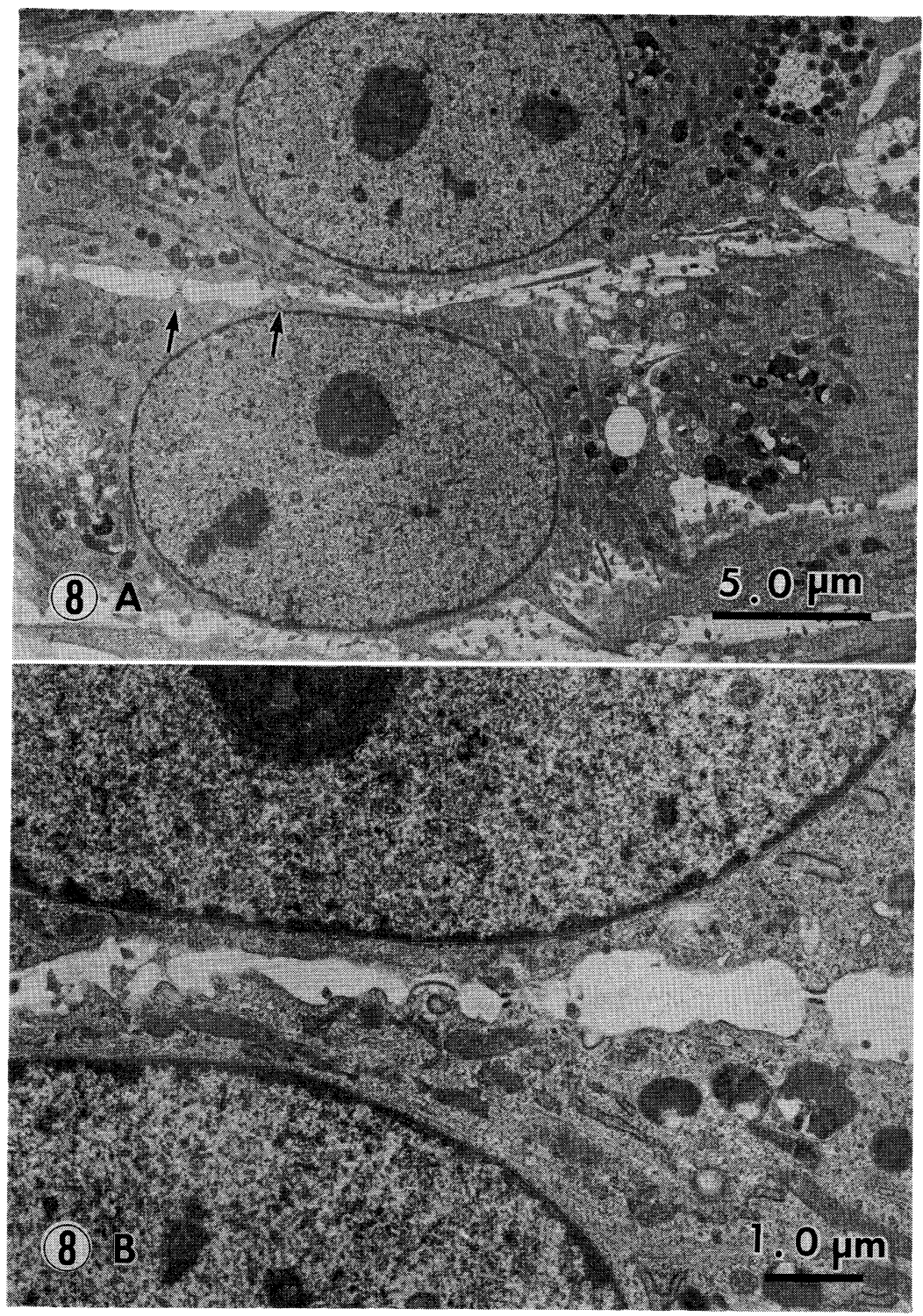

Fig. 8-A Electron micrograph of Fig. 5-C (cells derived from alveolar bone).

These cells have the decreased cytoplasmic volume, and ovoid shaped nucleus.

Fig. 8-B High-power magnification of Fig. 8-A (arrowed). Attachment site (cell junction) is observed.

歯肉由来細胞の細胞質内には, r-ER の拡張が目立って 見られた。細胞突起が互いに伸展してきており，ところ どころ細胞突起の断端が見え, オーバーラップが観察さ れた。細胞間に matrix 様物質の形成が認められるもの の, 細胞と根象牙質面間には, そのような物質は何ら認
められず, 細胞と根面との関係は 1 日目と特に変化はな かった (Fig. 13-A)。

歯根膜由来細胞でも, 1 日目に比べ, 細胞突起の伸展 が見られ，細胞突起相互のオーバーラップが見られた。 しかし, 対根面関係では, 歯肉由来細胞と同様の所見し 


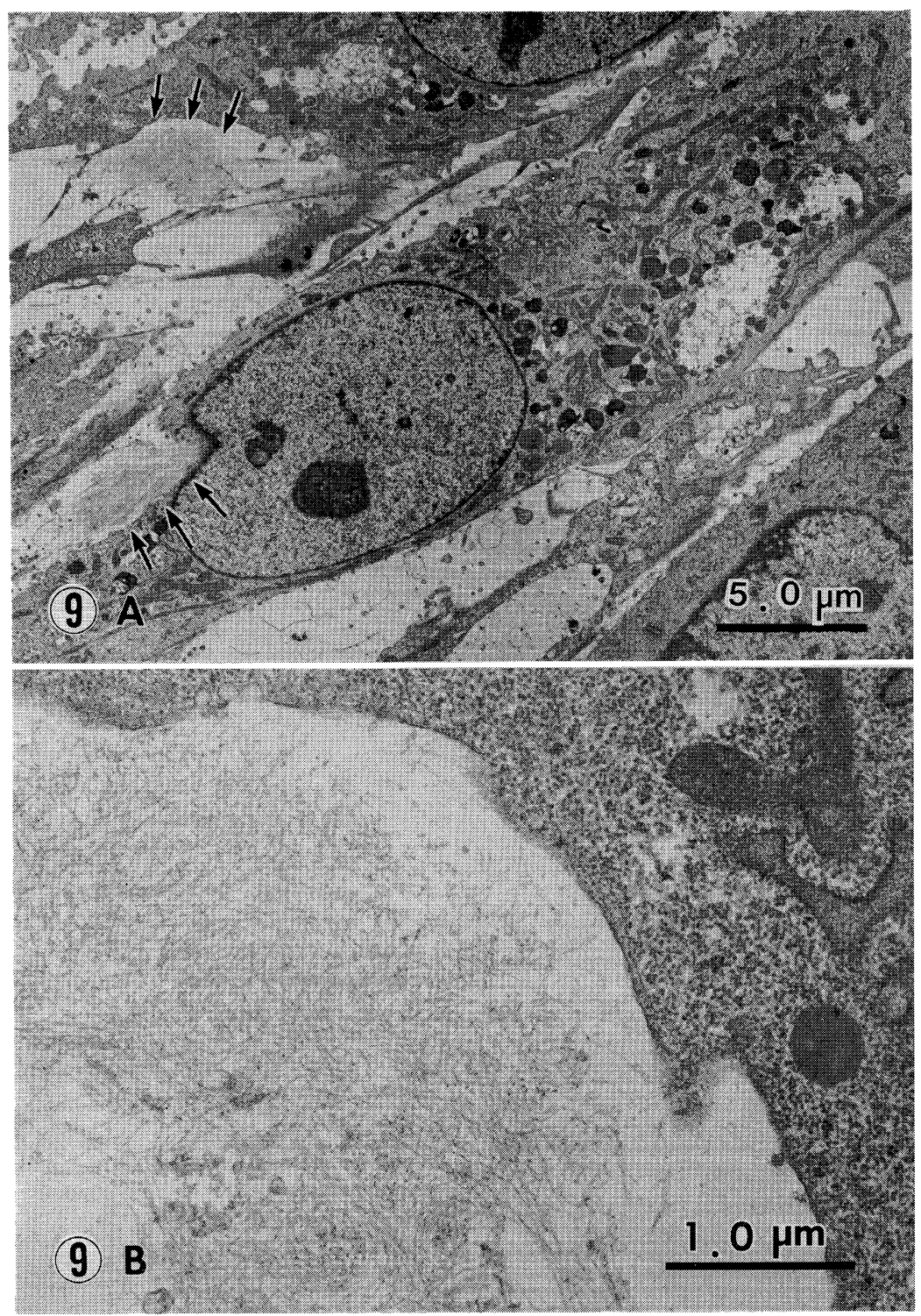

Fig. 9-A Electron micrograph of Fig. 5-C (cells derived from alveolar bone).

These cells have densely staining filament bundle and numerous phagolysosome.

Fig. 9-B High-power magnification of Fig. 9-A (arrowed). Immature micro-fibrills are observed at the extracellular portion.

か得られなかった (Fig. 13-B)。

一方, 歯槽骨由来細胞では, 前 2 者に比べて細胞内小 器官が豊富で, とくに Golgi apparatus, mitochondria が目立ち，象牙質との関係もより積極的で，細胞突起が
象牙質面に伸出していく様な像が見られた(Fig. 13-C)。 培養 7 日

歯肉由来細胞は， 1 日， 3 日目と比べて細胞内小器官 が目立ち，象牙質面により密着する傾向を示したが，明 


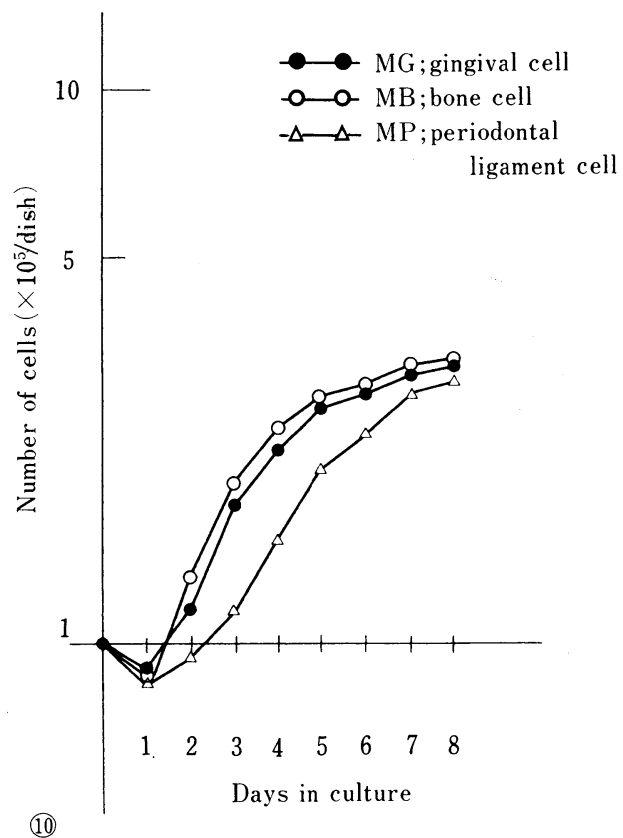

Fig. 10 Growth curve of culture cells derived from gingival connective tissue, periodontal ligament and alveolar bone.

Only periodontal ligament cells have a time lag $(24 \mathrm{hr})$ on cell-growth.

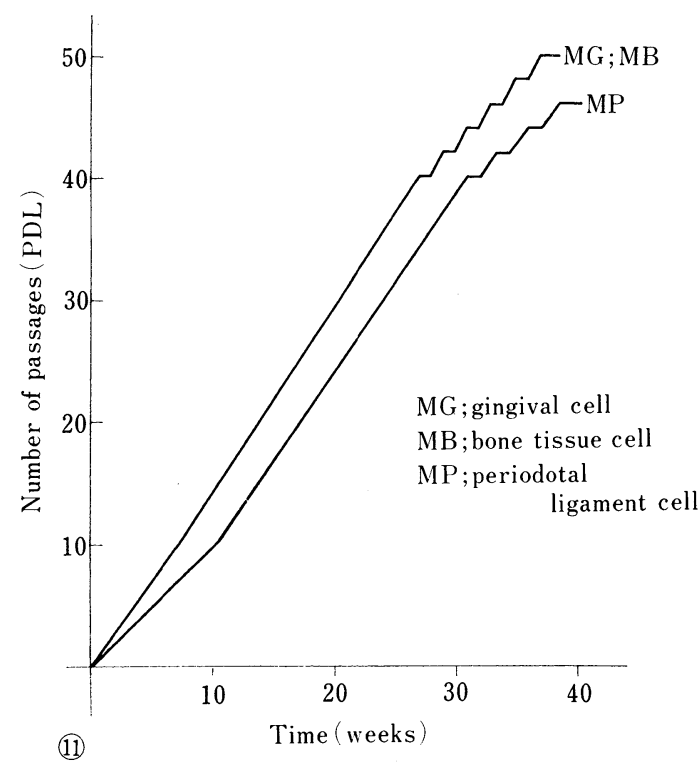

Fig. 11 Life span of culture cells derived from gingival connective tissue, periodontal ligament and alveolar bone.

The findings of transformation are not observed.

Table 2 Doubling time and saturation density of cells derived from gingival connective tissue, periodontal ligament and alveolar bone.

The doubling time and saturation density were calculated from the $\log$ of growth curve.

\begin{tabular}{c|c|c|c}
\hline & $\begin{array}{l}\text { cells derived from } \\
\text { gingiva }\end{array}$ & $\begin{array}{l}\text { cells derived from } \\
\text { periodontal ligament }\end{array}$ & $\begin{array}{c}\text { cells derived from } \\
\text { alveolar bone }\end{array}$ \\
\hline $\begin{array}{c}\text { doubling } \\
\text { time }(\mathrm{hr})\end{array}$ & 50.1 & 63.0 & 45.2 \\
\hline $\begin{array}{c}\text { saturation } \\
\text { density } \\
\left(\times 10^{3} \text { cells }\right)\end{array}$ & $314.2 /$ dish & $300.3 /$ dish & $317.3 /$ dish \\
\hline
\end{tabular}

白な付着機構の形成は認められなかった。また細胞と象 牙質面間には，細胞乫起の断端が見られるものの，その 間に matrix 様物質の形成は認められなかった (Fig. 14A)。

歯根膜由来細胞においても，歯肉由来細胞と同様の所 見を呈し, 根面との関倸は 3 日目と何ら変化はなかった (Fig. 14-B)。

しかし, 歯槽骨由来細胞は, 細胞内微細構造の発達は
3 日目と比べてほとんど変化はみられないものの, 細胞 のほぼ全域が歯根表面に近接するのがみられ（Fig. 14C), 特に密着している部分 (Fig. 14-C, arrows) では, Fig. 15 に示すような細胞膜の肥厚が観察された。

\section{考察}

歯肉剝離搔爬手術後, 再生歯肉により適切な根面性状 


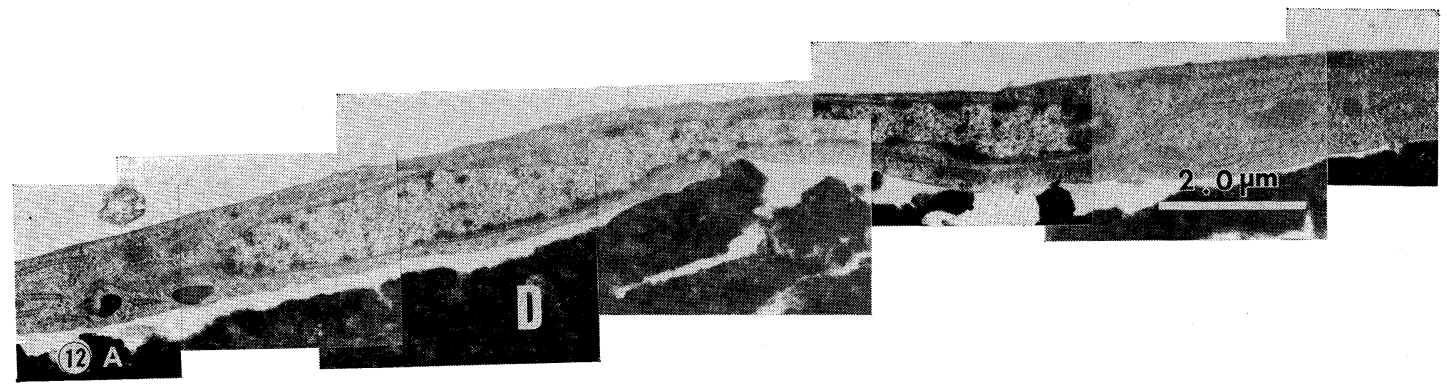

Fig. 12-A Electron micrograph of the cell derived from gingival connective tissue co-cultured with the dentin slice.

After 1 day of culture. Cell processus overgrow on the dentin surface, but the organella don't develop.

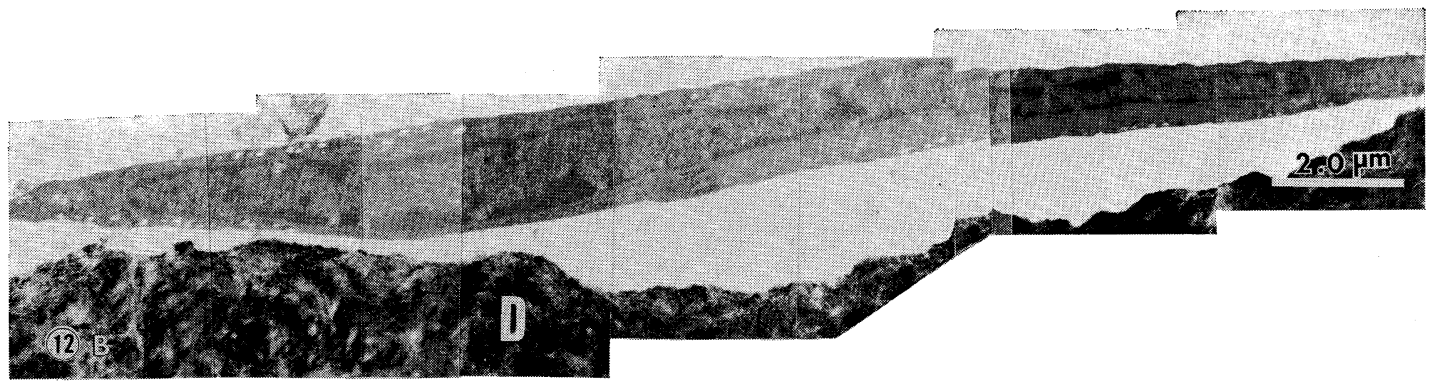

Fig. 12-B Electron micrograph of the cell derived from periodontal ligament co-cultured with the dentin slice.

After 1 day of culture. This cell resembles the feature of gingival fibroblast (Fig. 12-A).

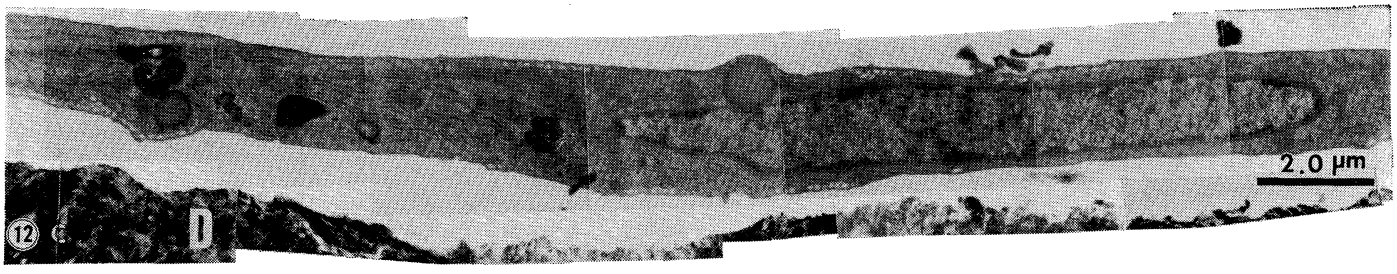

Fig. 12-C Electron micrograph of the cell derived from alveolar bone co-cultured with the dentin slice.

After 1 day of culture. There are some phagolysosome, lipid droplet, pinocytic vesicle and well-developed r-ER in cytoplasm.

を提供するため, 現在, 種々の根面処理法が試みられて いる ${ }^{1210)}$ 。一方, 新付着成就には, 根面上に集積する細胞

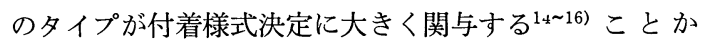
ら，セメント質形成能を有する細胞を選択的に根面に集 合させる努力が払われている。さらに現在, 新付着成就 にどのような細胞群が関与するか検索するため, 多彩な アプローチがなされている。現在まで, in vivo の実験系 でこの点を追求した報告は数多い11 16,21,26 28) が, 検索に 伴う付随的要因が多いため, 最近では, 細胞そのものに
焦点をあてた研究が増加している。Melcher ら(1986) ${ }^{38)}$ は, 歯肉由来, 歯根膜由来および骨由来細胞を歯根片と ともに各々培養し，その硬組織形成能を比較しているも のの, 培養細胞の種統一性に欠ける。しかも, それら細 胞群の増殖能力, 移動能力の差を同時に比較していな い。また Marmary ら (1976) ${ }^{39)}$ は, 上皮細胞と歯根膜 細胞の増殖能を比較しているが, 歯肉由来細胞および歯 槽骨由来細胞に関しての検討は行っていない。 そこで本実験においては，治癒に関与するであろう細 


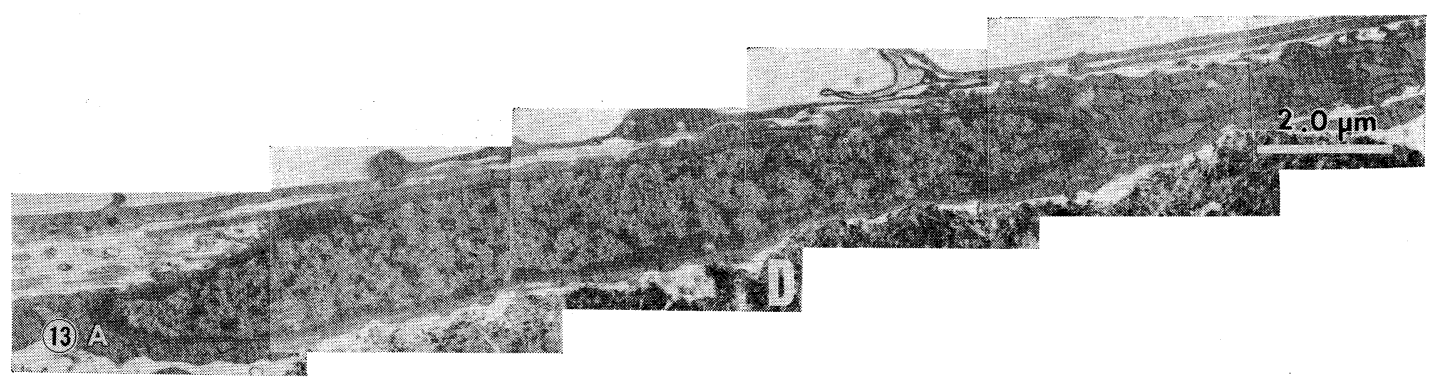

Fig. 13-A Electron micrograph of the cell derived from gingival connective tissue co-cultured with the dentin slice.

After 3 days of culture. There is no extracellular matrix between the culture cell and the dentin slice, but there are more developments of the organella in cytoplasm.

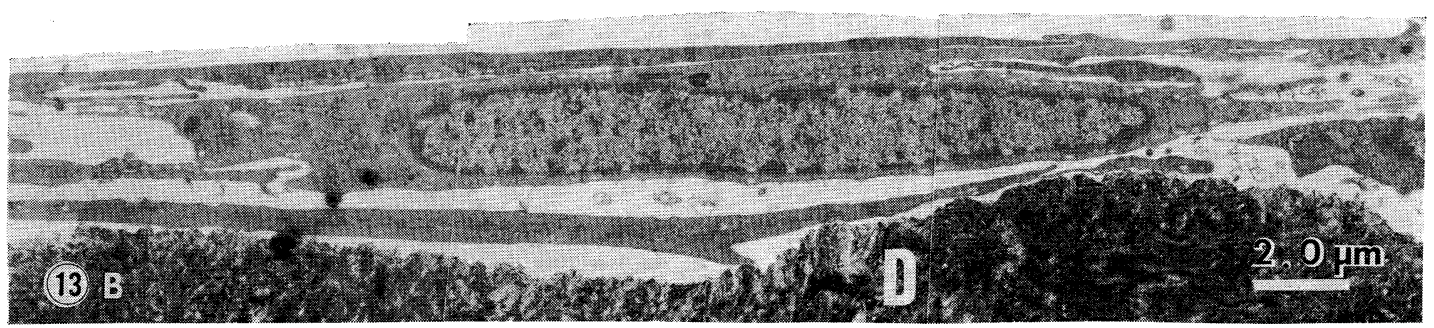

Fig. 13-B Electron micrograph of the cell derived from periodontal ligament co-cultured with the dentin slice.

After 3 days of culture. There are many cell processus piled up on the dentin slice, but the morphological changes of organella are not observed.

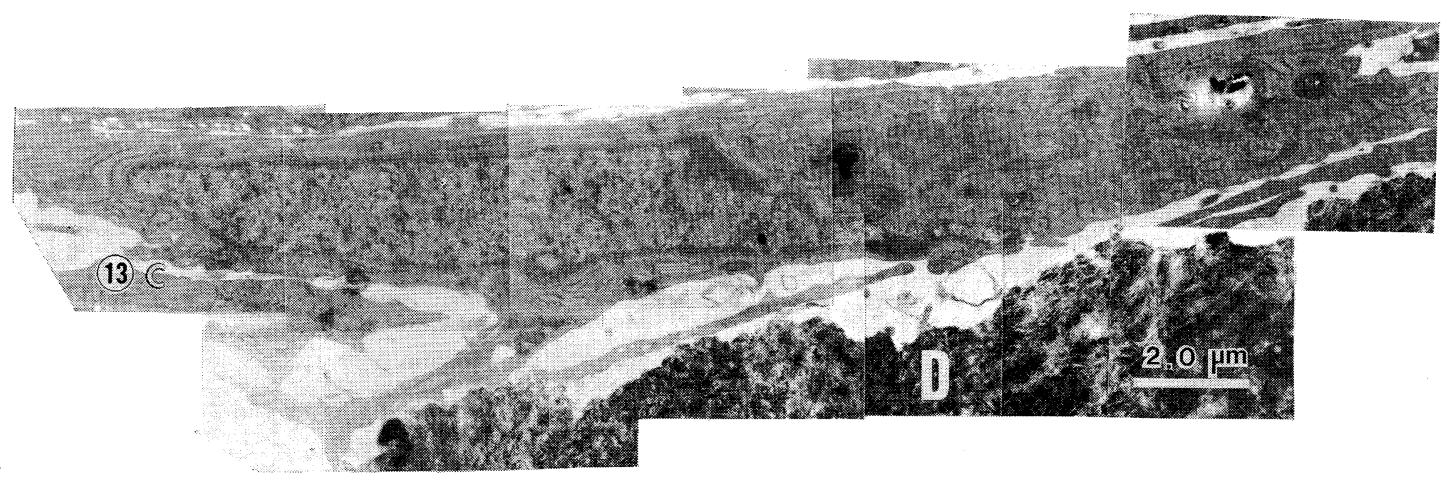

Fig. 13-C Electron micrograph of the cell derived from alveolar bone co-cultured with the dentin slice.

After 3 days of culture. This culture cell has well-developed mitochondria and Golgi apparatus. There is the cell process extended to the dentin surface.

胞群, すなおち, 歯肉由来細胞, 歯根膜由来細胞および 歯槽骨由来細胞を同一個体のサルより単離, 培養し, そ れら各細胞の増殖能力ならびに根面との付着能力を検索 した。

1. 培養細胞の由来について

初代培養の方法には, 現在大きく分けて, 酵素 (コラ
ゲナーゼ）により分離, 培養する方法, および培養皿に 組織片を貼り付け, 種々の細胞を誘導させる貼り付け法 がある。本研究の初代培養は, 後者の貼り付け法で行っ た。貼り付け法の場合, 得られる細胞は, Explant 片中 に含まれる種々の細胞集積から遊出するので, 線維芽細 胞以外の細胞, 例えば, 血管内皮細胞なども出現する可 


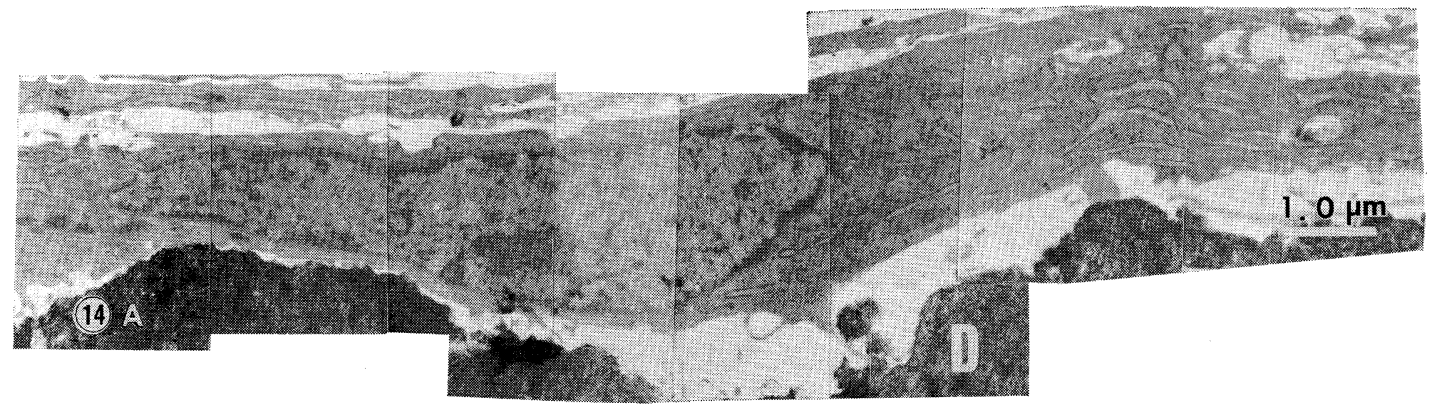

Fig. 14-A Electron micrograph of the cell derived from gingival connective tissue co-cultured with the dentin slice.

After 7 days of culture. The cell intimately attached to the dentin surface is observed. However, there is no extracellular matrix between the cell and the dentin surface.

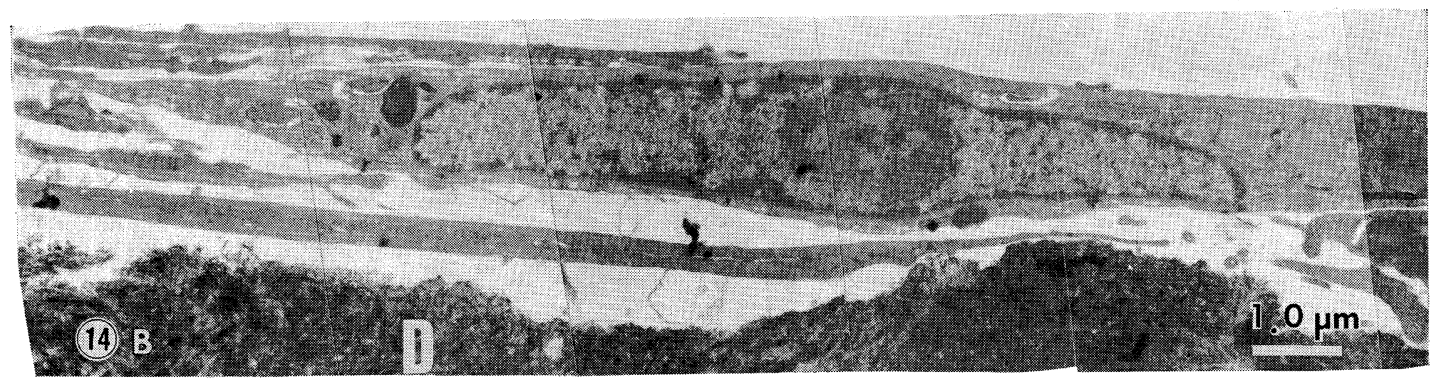

Fig. 14-B Electron micrograph of the cell derived from periodontal ligament co-cultured with the dentin slice.

After 7 days of culture. This cell resembles the 7 day's feature of the gingival cell.

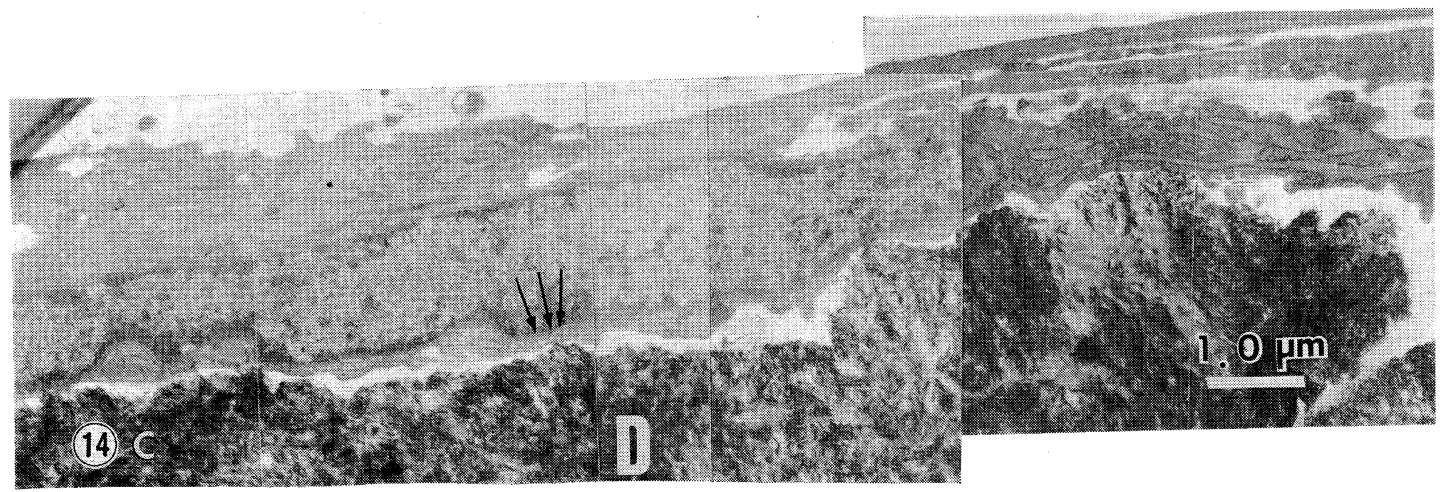

Fig. 14-C Electron micrograph of the cell derived from alveolar bone co-cultured with the dentin slice.

After 7 days of culture. This cell attaches to the dentin surface extensively, and more developed organella are observed.

能性が大きい。しかし, 酵素による単離法と比較して, 細胞ダメージが少なく，in vivo の特徴を反映した細胞 が得られるという利点がある。

一般に, 培養線維芽細胞の由来は次の様に考えられて
いる。第一に, 線維芽細胞の幹細胞からの由来, 第二は, 上皮細胞が脱分化し線維芽細胞へ変化し由来, 第三は, 血管内皮細胞から由来するというものである ${ }^{40)}$ 。今回の 初代培養で得られた各細胞群の形態像は, 核が球形また 


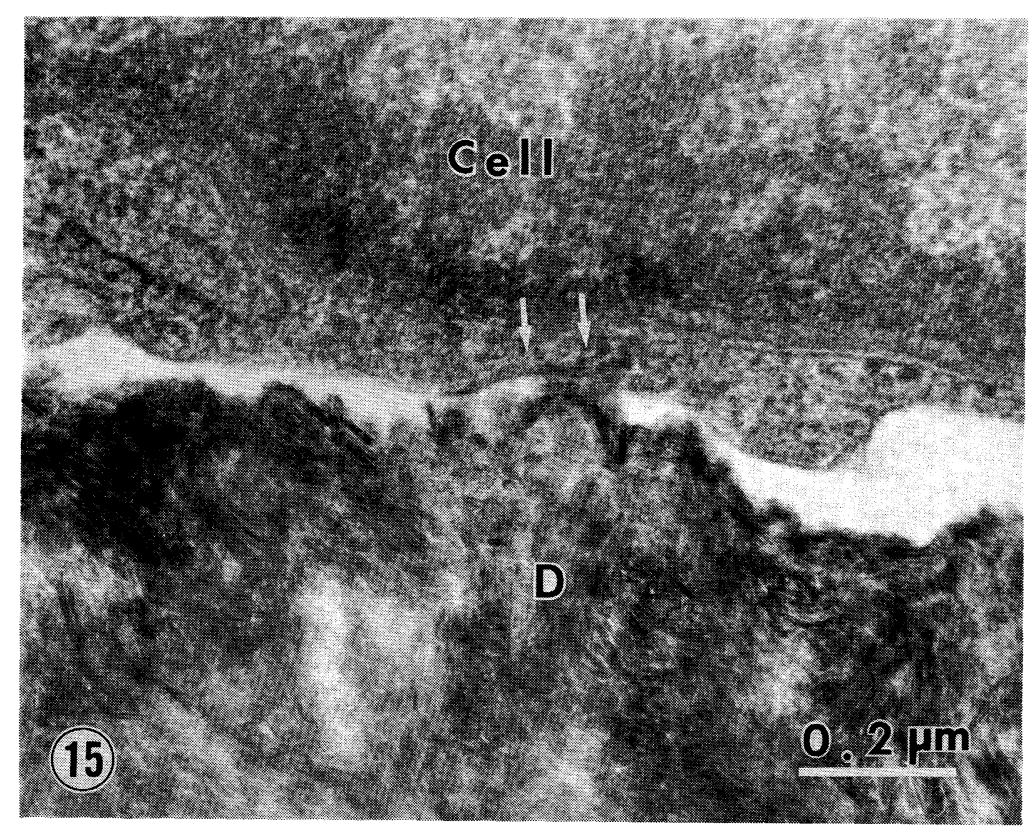

Fig. 15 High-power magnification of Fig. 14-C (arrowed).

There are small areas of increased density on the plasma membrane (white arrows).

は卵円形, 細胞質の r-ER や Golgi apparatus が未発 達で, 細胞突起は少ない。この特徴は, 組織切片中の毛 細血管周囲細胞あるいはその周囲の結合組織中の細胞に 似ている。さらにこの所見は，血管内皮細胞の特徴的所 見（核が小さく，細胞質に発達したr-ER, 大きな Golgi apparatus, autophagic vacuole を有し，多くの細胞突 起を持つ）と異なっていることから，これら細胞が結合 組織に由来することを示唆している。

通常, その結合組織細胞が器官の性質を決定する ${ }^{41)} こ$ とから, 結合組織に器官決定因子が存在すると見て良 い。今回得られた細胞群は, 結合組織由来といえ, 十分 その組織特異性を有しているといえる。

また前述したように，貼り付け法の問題点には上皮細 胞の混入がある。ヒトの歯根膜組織を酵素による分離法 で培養した Ragnarsson (1985) ${ }^{42)}$ は，そこから上皮様細 胞と線維芽細胞様細胞の二者を単離している。一方,

Brunette ら (1977) ${ }^{43)}$ がサル (Macaca irus) 歯根膜, そして Blomlof and Otteskog (1981) ${ }^{44)}$ がヒト歯根膜 を貼り付け法で培養しているが, やはり上皮様細胞と線 維芽細胞様細胞両者の単離を認めている。今回の歯根膜 由来細胞群には, 上皮様細胞の混入は見られず, 歯肉由 来細胞においてのみその派生が見られた。しかし，その
上皮様細胞も，0.25\%トリプシンにおいてはシャーレ面 から剝がれず, 継代を進めると希釈され, 最終的には線 維芽細胞の単一の集積となった。

\section{2. 培養細胞の同定について}

細胞間污染防止のため, 現在, 培養細胞株の使用に先 立ち, 細胞の性状解析が義務付けられている。本実験系 においても歯周組織各部の細胞を初代培養した後, その 性状解析のため, 染色体分析および形態学的分析を行っ た。染色体チェックの結果は, 各細胞とも細胞間污染は 無く, 染色体数 42 の二倍性細胞で, 正常性 $85 \%$ 以上を 維持していた。この值は, これら培養細胞が実験に使用 し得る十分な正常性を示している。またこの事を追証す る意味で, これら細胞群を実験使用後も継代を続け, 生 存曲線を作成した。その結果, 細胞自身の形質転換は観 察されず, 継代 50 代前後で死滅期へと移行した。この所 見は，“ヒトの正常細胞は自然形質転換はせず，継代 50 代前後で分裂できなくなる”という Hayflick and Moorhead $(1961)^{45)}$ の所見と一致する。

In vivo と in vitro の細胞の類似性に関しては, Ten Cate (1972) ${ }^{46)}$ は, 両者間では構造が幾分異なると述べ, in vitro の細胞では, r-ER が少なく, collagen coating vacuole は見られなかったとしている。また Nishimura 
ら (1985) ${ }^{47)}$ は， ヒト歯肉線維芽細胞の in vivo と in vitro（PDL 20）の超微形態を比較検討したところ, in vitro の細胞質内には, free ribosome, 微細線維が特に多 いとし，両者間に差異を認めている。本実験の継代 3 〜 5 代の各培養細胞は, in vivo の細胞に比べやや未分化な 像を呈するものの, オリジナルの形態学的特徴を有して いた。

各細胞の形態学的分析については, 光学ならびに電子 顕微鏡的アプローチによった。光顕的には, どの細胞も 正常細胞特有の接触阻止現象 (contact inhibition) の性 質を有し，pile up の所見は見られなかった。歯肉由来 細胞および歯根膜由来細胞の形態は, Brunette ら $(1976)^{48)}(1977)^{43)}$, Rose ら $(1980)^{17)}(1987)^{49)}$, Pitar u and Melcher (1983) $)^{50)}$ の観察と同様, 線維芽細胞様形 態を呈した。歯根膜由来細胞は, 歯肉由来細胞に比べて 不均一な様相を呈するが，その他では差異はなかった。 しかし，歯槽骨由来細胞は，その形状がモザイク様を呈 し, Sudo ら (1983) ${ }^{51)}$ の分離, 培養したマウスのカルバ リア由来骨芽細胞ときわめて類似していた。超微構造的 には, Engel ら (1980) ${ }^{52)}$ がヒト歯肉由来細胞, Rose ら $(1987)^{49)}$, Gould (1983) $)^{53)}$ が歯根膜由来細胞，そして Sudo ら (1983) $)^{51)}$, Escarot-Charrier ら $(1983)^{54)}$, Bab ら (1984) $)^{55)}$ が骨由来細胞の超微構造を検索している。 今回の所見はそれぞれ，彼らの所見と概ね一致してい た。因みに, 本実験で得られた歯槽骨由来細胞は, 微細 線維, lysosome, r-ER, Golgi apparatus が核周囲に多 く見られ，細胞質に比べ核の占める割合が多く, Sudo ら $(1983)^{51)}$ のカルバリア由来骨芽細胞と合致する像を示 した。また, 骨由来細胞にのみ, 細胞外で未熟な微細線 維の形成や, 細胞間結合の形成が見られた。すなわち, 培養期間の同じ三種の細胞間で，骨由来細胞のみに見ら れたことは，この細胞が他の細胞に比べ，定常期に入る のが速く，かつ蛋白合成速度も他の細胞より速いことを 意味しており, 後述の増殖能と関連して興味ある所見と いえる。

\section{3. 各種培養細胞の増殖能について}

根面との治癒様式を決定する重要因子の一つとして, 治瘺に関与する細胞の増殖能がある。今回本実験では, 各組織由来細胞の増殖能を検索対象の一つとした。Marmary ら (1976) ${ }^{39)}$ は, サル (Macaca irus) の歯根膜由 来培養細胞の増殖能について検索し, その倍加時間は約 17 時間であったと報告している。しかし, 今回のデータ によると, 歯根膜由来細胞の倍加時間は, 60.1 時間と大 幅に遅れていた。また, 歯肉由来細胞, 歯槽骨由来細胞
も各々, 50.1 時間, 45.2 時間と全体的に長く, Paul $(1970)^{56)}$ が記載している一般的な fast growing cell の 倍加時間の範囲を越えていた。このことは, まず第一に, 今回使用した細胞が継代初期の $3 \sim 5$ 代のものであり, 完全な対数増殖期に入っていないこと（生存曲線に示す ように 10 代以降では, 増殖率はあがっていた), 第二に, 自己樹立株細胞を使用したために，トリプシン処理によ るダメージが影響したことが考えられる。いずれにして も, 歯根膜由来細胞のみ特に低かったことは, この細胞 が分裂, 増殖するのに必要な最低接種数が他の細胞より 多い事を示唆している。すなわち同一条件下での本実験 では, 歯肉由来細胞および歯槽骨由来細胞と, 歯根膜由 来細胞との倍加時間の相違, ならびに対数増殖に入るま での time lag の相違が認められ, 興味深い。これに加 えて, 初代培養時の組織片からの紹胞遊出も歯根膜由来 細胞が他の細胞に比べて遅れたことから，歯根膜由来の 細胞が他の細胞に先駆けて歯冠側へ移動する可能性の低 い事を示唆した。

一方，各細胞群のオリジナルな位置的関係から歯肉剝 離搔爬術後の細胞集積を単純に考えると, 術後根面へ集 積する可能性が高い細胞群は歯肉由来細胞である。従っ て現在，この細胞群の根面への接触を防ぎ，優先的に歯 根膜由来細胞を根面に参集させる試みがある ${ }^{11 ~ 13,57,58) 。 ~}$ Gottlow ら (1984) ${ }^{12)}$, Nyman ら (1982) $)^{23)}$ は, 根面と 剝離歯肉弁との間にミリポアフィルターを介在させるこ とによって, 根面に多量の新生セメント質の形成を見て いる。そして, 彼らはその新生セメント質が歯根膜由来 細胞によってのみ形成されたと限定し，この時点では後 年, Petterson and Aukhil (1986) ${ }^{13)}$, Aukhi ら (1986) ${ }^{57)}$ $(1987)^{58)}$ が, 彼らの一連の研究で指摘している歯槽骨 由来細胞関与の可能性を考慮していない。

Nishimura ら (1984) $)^{33)}$, 高田 $(1985)^{34)}$, 野口 (1984) $)^{35)}$ は, サル (Macaca irus) に歯肉剥離搔爬手術を行い, そ の治癒過程を観察したところ, 骨の再生という組織環境 が，対応根面上での術後の新付着を促進する重要な因子 として作用することを指摘している。また, Stahl (1977) ${ }^{59)}$ は骨内欠損へ脱灰骨移植を行い, その結果，骨 再生という現象を促す事により近接根面に骨様セメント 質形成を見ている。さらに永石 $(1987)^{60)}$ も Stahl $(1977)^{59)}$ と類似した実験を行ったところ, 根面に骨芽細 胞様細胞が活発にセメント質形成を行っている電顕像を 観察し，骨再生時には，骨類似細胞によってセメント質 形成が行われることを示している。Melcher ら(1986) ${ }^{38)}$ もまた，彼らの行った実験から，歯槽骨由来の細胞が近 
接根面へ移動していく可能性を全く否定することができ ないとしている。以上のことと本実験結果を照らし合わ せると, ミリポアフィルター介在によって得られた新生 セメント質は, 歯根膜由来細胞の参画によってなされた ものでなく, 歯根膜由来細胞の増殖に先駆けて起こる歯 槽骨由来細胞の増殖が何らかの形で関与していることは 濃厚である。

\section{4. 各種培養細胞の根象牙質面への付着について}

細胞が分化していく足場としての根面性状の果たす役 割はきわめて大きい。Aukhilら (1986) ${ }^{61)}$ は歯周組織創傷 治瘾中に, 前セメント芽細胞がセメント芽細胞に分化す るには，根象牙質面に接する必要があると述べている。

Nishimura ら (1985) 62) は, 種々の根面操作を施した歯 周疾患罹患歯根面に培養細胞（歯肉由来線維芽細胞）を 付着させ, その根面性状の有効性を検索している。その 結果, 深層セメント質保存面, 深層セメント質クエン酸 処理面に細胞との親和性がみられたとしている。しか し, 現在のところ, 治痖に関与する細胞群の差異が, 根 面に対しどのような対応をするかを検索したものはみら れない。そこで今回著者は, 象牙質面に対する歯周組織 各部由来の細胞群の対応を検討した。

本実験結果によると，培養 1 日目では，ぞの細胞も根 面にただ接するだけで, その付着様式には大差はみられ なかった。3日目に打いても 1 日目之同様, 何ら付着様 式には変化は見られなかった。しかし, 骨由来細胞の rER, Golgi apparatus は発達し, 多数の mitochondria, free ribosome がみられ，細胞の活性の高さを示した。 一方, 歯肉由来あるいは歯根膜由来細胞は, 細胞内小器 官の発達程度は低く, これら両細胞の根面への親和性の 弱さを示した。他方, 細胞外物質の形成は, 3 日目で各 試料の細胞-細胞間に認められたものの, 細胞-根面間に は 7 日目になってもどの試料にも見られなかった。同様 の実験を行っている Melcher ら (1986) ${ }^{38)}$ も培養 7 日目 では, 根面一細胞間に matrix 様物質の形成を認めてお らず，この形成にはより長期の培養期間が必要と思われ た。しかし，7日目において見られた骨由来細胞の細胞 質膜肥厚は, 付着機構の形成を思わせ, 興味深い。

ところで, これら各細胞が将来セメント質形成を行う かどうかは今後の検索対象となるが，各種培養細胞の産 生する物質についての報告は多い63 67)。Simmons ら $(1982)^{63)}$ は, 胎坚ラットカルバリアから単離した骨由来

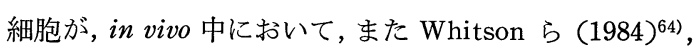
Bellows ら (1986) ${ }^{65)}$ は in vitro に扔いて, 骨由来細胞 による骨様組織の形成を証明 (これらの骨様組織は,
Type I コラーゲン, アルカリフォスファターゼ活性，そ して osteonectin の優位の存在により特徵づけられてい る)している。さらに, Melcher ら (1986) $)^{38)}$ は, 骨由 来細胞を根面上で一カ月培養することにより, 無細胞性 のセメント質様物質の形成をみている。このことは，骨 組織とセメント質は血液供給の有無により区別されるの みで, 形態的にほぼ類似した構造を有し68 72), また両者 は, 発生学的に同系統である ${ }^{73,74)}$ から必ずしも奇異なこ とではない。従って, 今回分離, 培養した骨由来細胞 を, 今後, より長期に培養を続けると, 根面上に骨様セ メント質を形成する可能性も高い。反面, Melcher ら $(1986)^{38)}$ はその実験で, 歯肉由来および歯根膜由来の細 胞群ではセメント質の形成はなかったと報告している。 このようなことから, 創傷治癒時に, もし増殖能の高い 骨由来細胞が直接根面に関与するようであれば，それら が骨様セメント質形成による新付着成就に寄与寸ること も十分考えられる。

5. 新付着を促す細胞群ならびに新付着の可能性につ いて

健全歯のセメント質は, それに近接するセメント芽細 胞によって必要に応じて形成されるが, 既存のセメント 質を除去した象牙質面には, 発生学的見地から, 本来の セメント芽細胞は再び得ることができないと Stahl ら $(1972)^{75)}$, Stahl (1977) ${ }^{76)}$ は述べている。そのため, 再 生セメント質に関して, とりわけその形成に関与する細 胞群について種々の論義がかわされているが, 現在のと ころ一応, 多潜能性を有する歯根膜由来細胞がその役割 を果たすと考えられている ${ }^{21,26 ~ 28)}$ 。他方, 歯肉由来細胞 を脱灰象牙質基質で培養することによって, matrix vesicle の形成をみたという Rose ら (1981 $)^{77)}$ の報告もあ るが,一般的にはこの細胞群には, セメント質形成能力 がないとされている ${ }^{14,16,21,23)}$ 。したがって従来から，七 メント質の再生に関して歯根膜細胞を対象とする研究が 多くみられる。歯根膜組織は, 厳密にいえば, セメント芽 細胞, 線維芽細胞および骨芽細胞の 3 種の phenotype を示す細胞群を含んでおり，不均一性 (heterogeneity) を有した組織であるといえる。すなわち，歯根膜組織中 央部の線維芽細胞は活発なコラーゲン代謝を行い, 歯根 膜線維の恒常性維持に奇与している ${ }^{78 \sim 80) か ゙ ， セ メ ン ト ~}$ 側, 骨側の細胞群は, 各々が独自のコラーゲン代謝, 分 裂活性を示し, 中央部の細胞群とは異なった行動様式を とる ${ }^{81,82)}$ 。

本実験で単離された歯根膜細胞はセメント質側組織か らのものであるが，本実験結果が示す様に，増殖能力は 
他の細胞群（特に歯槽骨由来細胞）より劣り, かつ傷害 に対する反応も time lag を有したことから, この細胞 の歯冠側への移動能力は低いと推察された。また McCulloch and Melcher (1983) ${ }^{83,84)}$, Davidson and McCulloch (1986) ${ }^{85)}$ は, 歯根膜細胞そのものの歯冠側一 の移動はあり得ないことでは無いが, 歯根膜そのものを 閉鎖的な組織と考えた方が良いとして，やはりその歯冠 側への移動を否定的にとらえている。加えて, Yamasaki ら (1987) ${ }^{86)}$ は, 歯根膜中の歯槽骨側の細胞は活発な蛋 白合成を示唆する像を呈するが，セメント質に接するセ メント芽細胞はほとんどが機能的に休止した状態である ことを示している。以上の見解と, 骨由来細胞が高い増 殖能を示した本実駼結果とを照らし合わせると, 新付着 に関与する細胞は，歯根膜由来細胞に先駆けて増殖する 歯槽骨由来細胞もしくはそれに類似した細胞と考えた方 が妥当なように思われる。最近, Caton ら (1987) 87 もま た根面への選択的細胞譑導に関する概念で, 骨由来細胞 の多大な根面への働きかけを指摘し，新付着への骨細胞 の関与も考虑しなければならないことを示唆している。

以上，本実験の結果と先人の報告から，歯槽骨頂対応 根面にみられるセメント質形成は, 歯槽骨由来細胞の根 面への直接移動によって行われるのではないか, あるい は近接する組織特性により同部の間葉細胞が骨類似細胞 に分化することによって行われるのではないか，などの 示唆を得たが，この点に関しては今後さらなる検討が必 要と考えられる。

\section{結 論}

歯肉剝離搔爬手術後の根面との新付着を促進する細胞 群の phenotype を検索するため, ニホンザル歯周組織 から歯肉結合組織, 歯根膜および歯槽骨由来細胞を単 離, 培養し, 得られた各培養細胞について形態的, 機能 的差異を比較検討した。

その結果，歯槽骨由来細胞の堌殖能が他の細胞より優 れており，根面に対する反応に関しても，歯槽骨由来細 胞が他の細胞より積極的な根面関係を示したことから， 歯槽骨頂部に限局して見られる新付着には, 少なくとも 骨芽細胞様細胞が関与するものと考える。

$$
\text { 謝辞 }
$$

稿を終わるにあたり，ご懇篤なご指導とご校閲を賜わった山 岡 昭教授に深甚の謝意を表します。

また，本研究に際し，ご教示をいただいた西村和晃講師をは
じめ,ご協力くださった教室員各位に感謝いたします。

\section{文 献}

1) Nishimura, K., Noguchi, Y., Hayashi, M. and Yamaoka, A. : Ultrastructural of new gingival attachment on various root surfaces (part 6). J. Electron Microsc., 36 : 107-116, 1987.

2) Blomlöf, L., Lindskog, S., Appelgren, R., Jonsson, B., Weintraub, A. and Hammarström, L. : New attachment in monkeys with experimental periodontitis with and without removal of the cementum. J. Clin. Periodontol., 14 : 136$143,1987$.

3) Horning, G.M., Cobb, C.M. and Killoy, W.J. : Effect of an air-powder abrasive system on root surfaces in periodontal surgery. J. Clin. Periodontol., 14 : 213-220, 1987.

4) Terranova, V.P., Franzetti, L.C., Hic, S., DiFlorio, R.M., Lyall, R.M., Wikesjö, U.M.E., Baker, P.J., Christersson, L.A. and Genco, R. J. : A biochemical approach to periodontal regeneration: Tetracycline treatment of dentin promotes fibroblast adhesion and growth. J. Periodontal Res., 21 : 330-337, 1986.

5) Sarbinoff, J.A., O'Leary, T.J. and Miller, C. H. : The comparative effectiveness of various agents in detoxifying diseased root surfaces. J. Periodontol., 54 : 77-80, 1983.

6) Register, A.A. and Burdick, F.A. : Accelerated reattachment with cementogenesis to dentin, demineralized in situ. J. Periodontol., 46 : 646655, 1975.

7) Caton, J.G., Polson, A.M., PiniPrato, G., Bartolucci, E.G. and Clauser, C. : Healing after application of tissue-adhesive material to denuded and citric acid-treated root surfaces. J. Periodontol., 57 : 385-390, 1986.

8) Daryabegi, P., Pameijer, C.H. and Ruben, M. P. : Topography of root surfaces treated in vitro with citric acid, elastase and hyaluronidase. J. Periodontol., 52 : 736-742, 1981.

9) Heritier, M. : Ultrastructural study of new connective tissue attachment following phosphoric 
acid application on human root dentin. J. Periodontol., $54:$ 515-521, 1983.

10) AL-Joburi, W.A., Denys, F.R. and Cogen, R.B. : Fluoride-treated roots and viability and attachment of human gingival fibroblasts. J. Dent. Res., 63 : 1206-1210, 1984.

11) Melcher, A.H. : Repair of wounds in the periodontium of the rat. Influence of periodontal ligament on osteogenesis. Archs oral Biol., 15 : 1183-1204, 1970.

12) Gottlow, J., Nyman, S., Karring, T. and Lindhe, J. : New attachment formation as the result of controlled tissue regeneration. J. Clin. Periodontol., 11 : 494-503, 1984.

13) Pettersson, E.C. and Aukhil, I. : Citric acid conditioning of roots affects guided tissue regeneration in experimental periodontal wounds. J. Periodontal Res., 21 : 543-552, 1986.

14) Melcher, A.H. : On the repair potential of periodontal tissues. J. Periodontol., $47: 256-$ 260, 1976.

15) Boyko, G.A., Melcher, A.H. and Brunette, D. M. : Formation of new periodontal ligament by periodontal ligament cells implanted in vivo after culture in vitro. J. Periodontal Res., 16 : 73-88, 1981.

16) Melcher, A.H. : Cells of periodontium : their role in the healing of wounds. Ann. Roy. Col. Surg. Eng., 67 : 130-131, 1985.

17) Rose, G.G., Yajima, T. and Mahan, C.J. : Human gingival fibroblast cell lines in vitro. J. Periodontal Res., 15 : 53-70, 1980.

18) Yajima, T., Rose, G.G. and Mahan, C.J. : Human gingival fibroblast cell lines in vitro. J. Periodontal Res., 15 : 267-287, 1980.

19) Yoshizato, K., Taira, T., Yamamoto, N. and Sasaki, K. : Remodeling of collagen : An in vitro model of connective tissue. Biomedical Res., 6 : 287-296, 1985.

20) Alberts, B., Bray, D., Lewis, J., Raff, M., Roberts, K. and Watson, J.D. : 中村桂子, 松原 謙一 (監訳) : 細胞の分子生物学, 教育社, 1985, 611-671.

21) Nyman, S., Karring, T., Lindhe, J. and Planten,
S. : Healing following implantation of periodontitis affected roots into gingival connective tissue. J. Clin. Periodontol., 7 : 394-401, 1980.

22) Line, S.E., Polson, A.M. and Zander, H.A.: Relationship between periodontal injury, selective cell repopulation and ankylosis. J. Periodontol., 45 : 725-730, 1974.

23) Nyman, S., Lindhe, J., Karring, T. and Rylander, H. : Nèw attachment following surgical treatment of human periodontal disease. J. Clin. Periodontol., 9 : 290-296, 1982.

24) Melcher, A.H. and Eastoe, J.E. : Connective tissues of the periodontium, In : Biology of the periodontium, Academic Press, London, 1969, 167-343.

25) Deporter, D.A. and Ten Cate, A.R. : Collagen resorption by periodontal ligament fibroblasts at the hard tissue-ligament interfaces of the mouse periodontium. J. Periodontol., 51 : 429432, 1980.

26) Nyman, S., Gottlow, J., Karring, T. and Lindhe, J. : The regenerative potential of the periodontal ligament. J. Clin. Periodontol., 9 : 257-265, 1982.

27) Karring, T., Isidor, F., Nyman, S. and Lindhe, J. : New attachment formation on teeth with a reduced but healthy periodontal ligament. J. Clin. Periodontol., 12 : 51-60, 1985.

28) Magnusson, I., Nyman, S., Karring, T. and Egelberg, J. : Connective tissue attachment formation following exclusion of gingival connective tissue and epithelium during healing. J. Periodontal Res., 20 : 201-208, 1985.

29) Nyman, S. and Karring, T. : Regeneration of surgically removed buccal alveolar bone in dogs. J. Periodontal Res., 14 : 86-92, 1979.

30) Polson, A.M. and Caton, J. : Factors influencing periodontal repair and regeneration. J. Periodontol., 53 : 617-625, 1982.

31) Stahl, S.S. and Froum, S. : Histological evaluation of human intraosseous healing responses to the placement of tricalcium phosphate ceramic implants. J. Periodontol., $57: 211-217$, 1986. 
32) Bogle, G., Claffey, N. and Egelberg, J. : Healing of horizontal circumferential periodontal defects following regenerative surgery in beagle dogs. J. Clin. Periodontol., 12 : 837-849, 1985.

33) Nishimura, K., Takada, K., Noguchi, Y., Yamaguchi, T. and Yamaoka, A. : Scanning electron microscopy of root surfaces, cementum, periodontal ligament and alveolar bone following periodontal surgery. J. Clin. Electron Microscopy., $17: 503-517,1984$.

34）高田耕平 : 歯肉剝離搔爬手術後の新付着に関する 研究一骨再生が新生セメント質形成に及ぼす影響 について. J. Clin. Electron Microscopy, 18 : 283-303, 1985.

35）野口吉廣 : 歯肉剝離搔爬手術後の歯肉の付着に関 する超微構造学的研究一外科的に象牙質を裸出さ せた根面に対する剝離歯肉弁の付着について. 日 歯周誌, $26: 21-48,1984$.

36）西村和晃，永石真幸，林 正純，白井義英，山田 実, 英保武志, 中谷 聡, 山岡 昭 : 歯肉剝離搔 爬手術後の新付着に関する研究 (第 12 報). 骨再 生が近接歯根面上へのセメント質形成に及ぼす影 響について. 日歯周誌, $29: 172-178,1987$.

37) Björn, H. : Experimental studies on reattachment. Dent. Pract., $11: 351-354,1961$.

38) Melcher, A.H., Cheong, T., Cox, J., Nemeth, E. and Shiga, A. : Synthesis of cementum-like tissue in vitro by cells cultured from bone : a light and electron microscope study. J. Periodontal Res., 21 : 592-612, 1986.

39) Marmary, Y., Brunette, D.M. and Heersche, J.N.M. : Differences in vitro between cells derived from periodontal ligament and skin of MACACA IRUS. Archs oral Biol., 21 : 709-716, 1976.

40) Franks, L.M. and Wilson, P.D. : "Spontaneous" neoplastic transformation in vitro: the ultrastructure of the tissue culture cell. Eur. J. Cancer, $6: 517-523,1970$.

41) Aronson, J.F., McClaskey, J.W. and Cristofalo, V.J. : Human fetal lung fibroblasts : observations on origin and stability in culture. Mech. Age. Dev., $21: 229-244,1983$.
42) Ragnarsson, B., Carr, G. and Daniel, J.C. : Isolation and Growth of human periodontal ligament cells in vitro. J. Dent. Res., 64 : 10261030, 1985.

43) Brunette, D.M., Kanoza, R.J., Marmary, Y., Chan, J. and Melcher, A.H. : Interactions between epithelial and fibroblast-like cells in cultures derived from monkey periodontal ligament. J. Cell Sci., 27 : 127-140, 1977.

44) Blomlöf, L. and Otteskog, P. : Composition of human periodontal ligament cells in tissue culture. Scand J. Dent. Res., 89 : 43-46, 1981.

45) Hayflick, L. and Moorhead, P.S. : The serial cultivation of human diploid cell strains. Exp. Cell Res., 25 : 585-621, 1961.

46) Ten Cate, A.R. : Morphological studies of fibrocytes in connective tissue undergoing rapid remodeling. J'. Anat., 112 : 401-414, 1972.

47) Nishimura, K., Noguchi, Y., Hayashi, M. and Yamaoka, A. : Ultrastractural comparison between human gingival fibroblasts in vitro and in vivo. J. Clin. Electron Microscopy., $18: 5-6$, 1985.

48) Brunette, D.M., Melcher, A.H. and Moe, H.K. : Culture and origin of epithelium-like and fibroblast-like cells from porcine periodontal ligament explants and cell suspensions. Archs oral Biol., 21 : 393-400, 1976.

49) Rose, G.G., Yamasaki, A., Pinero, G.J. and Mahan, C.J. : Human periodontal ligament cells in vitro. J. Periodontal Res., 22 : 20-28, 1987.

50) Pitaru, S. and Melcher, A.H. : Orientation of gingival fibroblasts and newly-synthesized collagen fibers in vitro. J. Periodontal Res., 18: 483-500, 1983.

51) Sudo, H., Kodama, H., Amagai, Y., Yamamoto, $\mathrm{S}$. and Kasai, S. : In vitro differentiation and calcification in a new clonal osteogenic cell line derived from newborn mouse calvaria. J. Cell Biol., 96 : 191-198, 1983.

52) Engel, D., Schroeder, H.E., Gay, R. and Clagett, J. : Fine structure of cultured human gingival fibroblasts and demonstration of simultaneous synthesis of types I and III collagen. 
Archs oral Biol., 25 : 283-296, 1980.

53) Gould, T.R.L. : Ultrastructural characteristics of progenitor cell populations in the periodontal ligament. J. Dent. Res., 62 : 873-876, 1983.

54) Escarot-Charrier, B., Glorieux, F.H., van der Rest, M. and Pereira, G. : Osteoblasts isolated from mouse calvaria initiate matrix mineralization in culture. J. Cell Biol., 96 : 639-643, 1983.

55) Bab, I., Howlett, C.R., Ashton, B.A. and Owen, M.E. : Ultrastructure of bone and cartilage formed in vivo in diffusion chambers. Clin. Orthop., $187: 243-257,1984$.

56) Paul, J. : Cell and tissue culture, 4th ed., Livingstone, Edinburgh and London, 1970.

57) Aukhil, I., Greco, G., Suggs, C. and Torney, D. : Root resorption potentials of granulation tissue from bone and flap connective tissue. $\mathrm{J}$. Periodontal Res., 21 : 531-542, 1986.

58) Aukhil, I., Pettersson, E. and Suggs, C. : Periodontal wound healing in the absence of periodontal ligament cells. J. Periodontol., $58: 71-$ 77, 1987.

59) Stahl, S.S. : Repair potential of the soft tissueroot interface. J. Periodontol., $48: 545-552$, 1977.

60）永石真幸 : 各種移植材がセメント質形成に及ぼす 影響について。歯科医学, 50 : 639-640, 1987.

61) Aukhil, I., Simpson, D.M., Suggs, C. and Pettersson, E. : In vivo differentiation of progenitor cells of the periodontal ligament. J. Clin. Periodontol., $13: 862-868,1986$.

62) Nishimura, K., Takada, K., Noguchi, Y. and Yamaoka, A. : Cell attachment of cultured fibroblasts to various root surfaces. J. Dent. Res., (Special issue), $64: 334,1985$.

63) Simmons, D.J., Kent, G.N., Jilka, R.L., Scott, D.M., Fallon, M. and Cohn, D.V. : Formation of bone by isolated, cultured osteoblasts in millipore diffusion chambers. Calcif. Tissue Int., 34 : 291-294, 1982.

64) Whitson, S.W., Harrison, W., Dunlap, M.K., Bowers, D.E. Jr., Fisher, L.W., Robey, P.G. and Termine, J.E.: Fetal bovine bone cells synthesize bone-specific matrix proteins. J.
Cell Biol., 99 : 607-614, 1984.

65) Bellows, C.G., Aubin, J.E., Heersche, J.N.M. and Antosz, M.E. : Mineralized bone nodules formed in vitro from enzymatically released rat calvaria cell populations. Calcif. Tissue Int., 38 : 143-154, 1986.

66) Majeska, R.J., Rodan, S.B. and Rodan, G.A. : Culture and activity of osteoblasts and osteoblast-like cells, ed. Butler, W.T., Birmingham, In : Chemistry and Biology of Minneralized tissues, Ebsco, 1985, 279-385.

67) Tung, P.S., Domenicucci, C., Wasi, S. and Sodek, J. : Specific immunohistochemical localization of osteonectin and collagen type I and III in foetal and adult porcine dental tissues. J. Histochem. Cytochem., 33 : 531, 1985.

68) Furseth, R. and Mjör, I.A. : Histology of the human teeth, 2nd ed., Copenhagen, Munksgaard, 1979, 105-123.

69) Freeman, E. : Periodontium. In : Oral histology : Development, structure, and function, ed. Ten Cate, A.R., 2nd ed., Saint Louis, C.V. Mosby, 1985, 234-263.

70) Armitage, G.C. : Cementum, ed. Bhaskar, S.N., In : Orban's oral histology and embryology, 10th ed., C.V. Mosby, Saint Louis, 1986, 175197.

71) Furseth, R.: The fine structure of cellular cementum of young human teeth. Archs oral Biol., 14 : 1147-1158, 1969.

72) Jande, S.S. and Bélanger, L.F. : Fine structural study of rat molar cementum. Anat. Rec., 167 : 439-464, 1970.

73) Freeman, E. and Ten Cate, A.R. : Development of the periodontium. An electron microscopic study. J. Periodontol., 42 : 387-395, 1971.

74) Ten Cate, A.R. : Formation of supporting bone in association with periodontal ligament organization in the mouse. Archs oral Biol., 20 : 137138, 1975.

75) Stahl, S.S., Slavkin, H.C., Yamada, L. and Levine, S. : Speculations about gingival repair. J. Periodontol., 43 : 395-402, 1972.

76) Stahl, S.S. : Healing following simulated fiber 
retention procedures in rats. J. Periodontol., $48: 67-73,1977$.

77) Rose, G.G., Yamasaki, A. and Mahan, C.J. : Bone induction in vitro. J. Periodontal Res., $16: 344-357,1981$.

78) Sodek, J. : A comparison of the rates of synthesis and turnover of collagen and non-collagen proteins in adult rat periodontal tissues and skin using a microassay. Archs oral Biol., 22 : 655-665, 1977.

79) Vignery, A. and Baron, R. : Dynamic histomorphometry of alveolar bone remodeling in the adult rat. Anat. Rec., 196 : 191-200, 1980.

80) Gould, T.R.L., Melcher, A.H. and Brunette, D.M. : Migration and division of progenitor cell populations in periodontal ligament after wounding. J. Periodontal Res., 15 : 20-42, 1980.

81) Roberts, W.E. : Cell kinetic nature and diurnal periodicity of the rat periodontal ligament. Archs oral Biol., 20 : 465-471, 1975.

82) Roberts, W.E. and Chase, D.C. : Kinetics of cell proliferation and migration associated with orthodontically-induced osteogenesis. J. Dent. Res., 60 : 174-181, 1981.

83) McCulloch, C.A.G. and Melcher, A.H. : Cell migration in the periodontal ligament of mice. J. Periodontal Res., $18: 339-352,1983$.

84) McCulloch, C.A.G. and Melcher, A.H. : Cell density and cell generation in the periodontal ligament of mice. Am. J. Anat., 167 : 43-58, 1983.

85) Davidson, D. and McCulloch, C.A.G. : Proliferative behavior of periodontal ligament cell populations. J. Periodontal Res., 21 : 414-428, 1986.

86) Yamasaki, A., Rose, G.G., Pinero, G.J. and Mahan, C.J. : Ultrastructural and morphometric analysis of human cementoblasts and periodontal fibroblasts. J. Periodontol., 58 : 192-201, 1987.

87) Caton, J.G., DeFuria, E.L., Polson, A.M. and Nyman, S. : Periodontal regeneration via selective cell repopulation. J. Periodontol., 58 : 546$552,1987$. 